\title{
A four-part working bibliography of neuroethics: part 2 - neuroscientific studies of morality and ethics
}

\author{
Martina Darragh", Liana Buniak² and James Giordano $2,3,4^{*}$
}

\begin{abstract}
Background: Moral philosophy and psychology have sought to define the nature of right and wrong, and good and evil. The industrial turn of the twentieth century fostered increasingly technological approaches that conjoined philosophy to psychology, and psychology to the natural sciences. Thus, moral philosophy and psychology became ever more vested to investigations of the anatomic structures and physiologic processes involved in cognition, emotion and behavior - ultimately falling under the rubric of the neurosciences. Since 2002, neuroscientific studies of moral thought, emotions and behaviors have become known as - and a part of - the relatively new discipline of neuroethics. Herein we present Part 2 of a bibliography of neuroethics from 2002-2013 addressing the "neuroscience of ethics" - studies of putative neural substrates and mechanisms involved in cognitive, emotional and behavioral processes of morality and ethics.

Methods: A systematic survey of the neuroethics literature was undertaken. Bibliographic searches were performed by accessing 11 databases, 8 literature depositories, and 4 individual journal searches, and employed indexing language for National Library of Medicine (NLM) Medical Subject Heading databases. All bibliographic searches were conducted using the RefWorks citation management program.

Results: This bibliography lists 397 articles, 65 books, and 52 book chapters that present (1) empirical/ experimental studies, overviews, and reviews of neural substrates and mechanisms involved in morality and ethics, and/or (2) reflections upon such studies and their implications. These works present resources offering iterative descriptions, definitions and criticisms of neural processes involved in moral cognition and behaviors, and also provide a historical view of this field, and insights to its developing canon.
\end{abstract}

Keywords: Neuroethics, Neuroscience, Morality, Moral Psychology, Ethics, Bibliography

\section{Introduction and background}

Throughout much of recorded history, humans have sought to define the nature of right and wrong, and good and evil. Since antiquity, such questions have been the focus of moral philosophy. However, empirical and experimental movements of the late nineteenth century drew scientific attention to philosophical questions, and the queries of moral philosophy became the focus of the

\footnotetext{
* Correspondence: james.giordano@georgetown.edu

${ }^{2}$ Neuroethics Studies Program, Edmund D. Pellegrino Center for Clinical Bioethics, Georgetown University Medical Center, Washington, DC 20057, USA

${ }^{3}$ Department of Neurology, Georgetown University Medical Center, Washington, DC 20057, USA

Full list of author information is available at the end of the article
}

then nascent discipline of psychology. The industrial turn of the twentieth century fostered increasingly technological approaches that conjoined psychology to the natural sciences. Philosophical speculation, and psychological observation and experimentation became ever more rooted in, and vested to investigations of the anatomic structures and physiologic processes involved in cognition, emotion and behavior. Thus, studies of moral philosophy and moral psychology became the province of brain research, ultimately falling under the rubric of the neurosciences, which became firmly established as a titular field in the middle-to-late 1970s [1]. Important contributory literature from the 1960s through early 2000 s is provided below. 
Important contributory literature from the 1960s through early 2000s

Journal Articles

Allison T: Neuroscience and morality. Neuroscientist 2001, 7(5):360-364.

Callahan D: Ethical responsibility in science in the face of uncertain consequences. Ann NY Acad Sci 1976, 265:1-12.

Changeux JP: [Reflections of a neurobiologist on the origin of ethics.] CR Seances Soc Biol Fil 1998, 192(6):1041-1049.

Churchland PS: The significance of neuroscience for philosophy. Trends Neurosci 1988, 11(7): 304-307 Damasio H, Grabowski T, Frank R, Galaburda AM, Damasio AR: The return of Phineas Gage: clues about the brain from the skull of a famous patient. Science 1994, 264(5162): 1102-1105.

Dolan RJ: On the neurology of morals. Nat Neurosci 1999, 2(11):927-929.

Eslinger PJ, Damasio AR: Severe disturbance of higher cognition after bilateral frontal lobe ablation: patient EVR. Neurology 1985, 35(12):1731-1741.

Greene JD, Sommerville RB, Nystrom LE, Darley JM, Cohen JD: An fMRI investigation of emotional engagement in moral judgment. Science 2001, 293(5537): 2105-2108.

Helmuth L: Cognitive neuroscience. Moral reasoning relies on emotion. Science 2001, 293(5537):1971-1972. Laplane D. [Epistemological remarks on the question of cerebral organization.] Rev Neurol 1994, 150(8-9):555-563.

Medinnus GR: Behavioral and cognitive measures of conscience development. J Genet Psychol 1966, 109(1):147-150.

Scoville WB, Milner B: Loss of recent memory after bilateral hippocampal lesions. J Neurol Neurosurg Psychiat 1957, 20:11-21.

Strawson G: The impossibility of moral

responsibility. Philos Stud 1994, 75(1/2): 5-24.

\section{Books}

Bratman M: Intention, Plans, and Practical Reason. Cambridge, Mass: Harvard University Press 1987. Brentano F: Psychology from an Empirical Standpoint. New York: Humanities Press 1973 (1874).

Churchland PM: The Engine of Reason, the Seat of the Soul: A Philosophical Journey into the Brain.

Cambridge, Mass: MIT Press 1995.

Clark A: Being There: Putting Brain, Body and World Together Again. Cambridge, Mass.: MIT Press 1997. Crick F: The Astonishing Hypothesis: The Scientific Search for the Soul. New York: Touchstone 1994.
Damasio AR: Descartes' Error: Emotion, Reason and the Human Brain. New York: Putnam 1994.

Damasio AR: The Feeling of What Happens: Body and Emotion in the Making of Consciousness. New York: Harcourt Brace 1999.

Dewey J. Human Nature and Conduct: An Introduction to Social Psychology. New York: Carlton House 1922.

Fodor JA: The Language of Thought. New York: Crowell 1975.

Habermas J, Dews P: Autonomy and Solidarity: Interviews with Jürgen Habermas. London: Verso 1986. Harrington A: Medicine, Mind, and the Double Brain: A Study in Nineteenth-Century Thought. Princeton, NJ: Princeton University Press 1987.

Huber G: Cerveau et Psychisme Humains: Quelle Ethique? [Human Brain: Which Ethics?] Paris:

Association Decartes and J. Libbey Eurotext 1996. Kane R: The Significance of Free Will. New York: Oxford University Press 1996.

Luria AR: The Man with a Shattered World: The History of a Brain Wound. New York: Basic Books 1972.

Minsky M: The Society of Mind. New York: Simon and Schuster 1986.

Nagel T: Equality and Partiality. Oxford and New York: Oxford University Press 1991.

Pylyshyn ZW: Computation and Cognition: Toward a Foundation for Cognitive Science. Cambridge, Mass.: MIT Press 1984.

Rolls ET: The Brain and Emotion. Oxford: Oxford University Press 1999.

Taylor C: Sources of the Self: The Making of Modern Identity. Cambridge, Mass.: Harvard University Press 1989.

Since 2002, neuroscientific studies of moral thought, emotions and behaviors have become known as - and a part of - the relatively new discipline of neuroethics [2]. As a field, neuroethics' focus is not limited to studies of neural bases of morality, but also centers upon those ethical issues that are fostered by neuroscientific research and its various implications and applications in clinical medicine and the public sphere. Thus, as the tools and techniques of neuroscience become more sophisticated and precise, the questions raised by neuroscience and neuroethics may be equally, or even more pressing as those answered [3]. How can -and will-the brain sciences inform concepts of morality, ethics and law? Will understanding the structure and functions of brain networks and processes involved in social interactions, emotions and behaviors alter constructs of "free will," culpability, and responsibility? Can neuroscientific information provide a basis for guiding how we should behave, either as individuals or as actors-in-community? Will the brain sciences foster a "new ethics" of neuroethics, 
and if so, how might these new ideas-and perhaps idealscomport with long held traditions and norms of morality and ethics on an ever more pluralistic world stage?

The late William Safire concluded his introductory remarks to the 2002 Dana Foundation conference "Neuroethics -Mapping the Field" by congratulating the attendees for tackling "...the challenge of carving out a new territory for an old philosophical discipline" [4] by examining the neural mechanisms of morality. The following bibliography reflects this challenging "new territory", as presented in published works from 20022013. These works are experimental, empirical, and/or hypothetical. In some cases the position is inquisitive, in others speculative, and in others a critical perspective is taken (of approaches used to exemplify and study ethical dilemmas, of the prior and current descriptions of psychological processes of human relations, and of concepts of morality and ethics, more generally).

\section{Methods}

Methods for systematically searching relevant literature devoted to neuroethics are identical to those utilized in Part 1 of this bibliography [5]. Search strategies utilizing MeSH (Medical Subject Headings: http://www.ncbi.nlm. nih.gov/mesh/) indexing terms were used for generating bibliographies from PubMed and National Library of Medicine (NLM) Catalog. MeSH includes ethics-related terms developed for BIOETHICSLINE, a specialty database devoted to bioethical issues produced for NLM by the Kennedy Institute of Ethics from 1975-2000. Other databases were searched using descriptors specific to those databases. The searches were limited to work published from 2002 to 2013.

The following databases were searched to produce this bibliography:

1) PubMed (http://pubmed.gov):

Search Strategy: (morals[majr:noexp] AND (neurosciences/ethics[majr:noexp] OR cognitive science/ethics[majr] OR brain[majr:noexp]))

2) The NLM Catalog (http://www.ncbi.nlm.nih.gov/ nlmcatalog):

Search Strategy: (morals [majr:noexp] AND (neurosciences/ethics[majr:noexp] OR cognitive science/ethics[majr] OR brain[majr:noexp]))

3) Academic Search Premier: Search Strategy: TX morality AND SU neurosciences AND SU philosophy

4) Proquest Research Library:

Search Strategy: su (morality) AND su (neurosciences)

5) JSTOR:

Search Strategy: ab:(moral) AND ab:(neuroscience)

6) WorldCat (http://www.worldcat.org)::
Search Strategy: "cognitive neuroscience" and "moral and ethical aspects" (as subject phrases)

7) Philosopher's Index:

Search Strategy: su(moral) AND su(neuroscience)

8) Embase:

Search Strategy: neuroscience:de AND morality:de

9) BELIT (http://www.drze.de/belit/).:

Search Strategy: neurosciences* [subject keywords] and morality" [subject keywords]

10) Web of Knowledge/Web of Science (WoS):

Search Strategy: [topic] morality neurosciences

11) Digital Public Library of America (DPLA) (http://dp.la/): Search Strategy: brain moral

12) Directory of Open Access Journals (DOAJ)

(http://www.doaj.org/):

Search Strategy: [search all] moral neurosciences

13) Hathi Trust Digital Library (http://www.hathitrust. org/):

[any of these words] morality moral in Subject AND [any of these words] neurosciences brain cognitive in Subject

14) European Library (http://www.theeuropeanlibrary. org/tel4/):

Search Strategy: [subject] moral AND [subject] brain

15) Internet Archive (http://archive.org/):

Search Strategy: morality AND brain

16) Globethics.net (http://www.globethics.net/):

Search Strategy: [keywords] moral AND neurosciences

17) Neuroethics-Wikiography (https://teamweb.uni-mainz. de/fb05/Neuroethics):

Search Strategy: moral

As previously noted [5], open access bioethics' journals not contained in the Directory of Open Access Journals (DOAJ) were individually accessed and searched; these included:

1) Journal of Ethics and Social Philosophy from the University of Southern California http://www.jesp.org/);

2) Journal of Mental Health Ethics from McMaster University (http://www.jemh.ca/);

3) Journal of Practical Ethics (http://www.jpe.ox.ac.uk/) from the Oxford Uehiro Centre for Practical Ethics at the University of Oxford; and

4) Philosophers' Imprint from the University of Michigan (http://www.philosophersimprint.org/).

As in Part 1 of this bibliography [5], the RefWorks citation manager program was utilized to eliminate $\mathrm{du}$ plicate reference citations.

\section{Results}

The following reference citations provide a listing of 397 articles, 65 books, and 52 book chapters that afford (1) 
empirical/experimental studies, overviews, and reviews of neural substrates and mechanisms involved in morality and ethics, and/or (2) reflections upon such studies and their implications.

- Abend G: Thick concepts and the moral brain. Euro J Soc 2011, 52(1):143-172. doi:10.1017/s00039 75611000051.

- Abend G: What the science of morality doesn't say about morality. Philos Soc Sci 2013, 43(2):157-200. doi:10.1177/0048393112440597.

- Adolphs R: The social brain: neural basis of social knowledge. Annu Rev Psychol 2009, 60: 693:716. doi:10.1146/annurev.psych.60.110707.163514.

- Adolphs R: Cognitive neuroscience of human social behaviour. Nat Rev Neurosci 2003, 4(3): 165-178. doi:10.1038/nrn1056.

- Agar N: Still afraid of needy post-persons. J Med Ethics 2013, 39(2):81-83. doi:10.1136/medethics2012-101095.

- Agar N: Why is it possible to enhance moral status and why doing so is wrong? J Med Ethics 2013, 39(2):67-74. doi:10.1136/medethics-2012100597.

- Ainslie G: Précis of breakdown of will. Behav Brain Sci 2005, 28(5):635-673. doi:10.1017/S01 $40525 X 05000117$.

- Al-Delaimy WK: Ethical concepts and future challenges of neuroimaging: an Islamic perspective. Sci Eng Ethics 2012, 18(3):509-518. doi:10.1007/ s11948-012-9386-3.

- Árnason G: Neuroscience, free will and moral responsibility. TRAMES-J Humanit Soc 2011, 15(2):147-155. doi:10.3176/tr.2011.2.03.

- Árnason G: Neuroimaging, uncertainty, and the problem of dispositions. Camb Q Healthc Ethics 2010, 19(2):188-195. doi:10.1017/S0963180 109990454.

- Avram M et al.: Neurofunctional correlates of esthetic and moral judgments. Neurosci Lett 2013, 534:128-132. doi:10.1016/j.neulet.2012.11.053.

- Azzone GF: The biological foundations of culture and morality. Rendiconti Lincei 2008, 19 (2):189-204.doi:10.1007/s12210-008-0011-y.

- Baertschi B: Neurosciences et neuroéthique: qui se ressemble s'assemble. Rev Med Suisse 2005, 1(34):2225-2229.

- Baertschi B: Neurosciences et responsabilité morale: un argument en faveur du compatibilisme. Revue de Theologie et de Philosophie 2011, 143(3):257-272.

- Bahnemann M et al.: Sociotopy in the temporoparietal cortex: common versus distinct processes. Soc Cogn Affect Neurosci 2010, 5(1):48-58. doi:10.1093/scan/nsp045.
- Banja J: Virtue essentialism, prototypes, and the moral conservative opposition to enhancement technologies: a neuroethical critique. $A J O B$ Neurosci 2011, 2(2):31-38. doi:10.1080/21507740. 2011.556918.

- Barandiaran X, Ruiz-Mirazo K: Modelling autonomy: simulating the essence of life and cognition. Introduction. Biosystems 2008, 91(2):295-304. doi:10.1016/ j.biosystems.2007.07.001.

- Barbey AK, Krueger F, Grafman J. An evolutionarily adaptive neural architecture for social reasoning. Trends Neurosci 2009, 32(12):603-610. doi:10.1016/j. tins.2009.09.001.

- Barraza JA, McCullough ME, Ahmadi S, Zak PJ: Oxytocin infusion increases charitable donations regardless of monetary resources. Horm Behav 2011, 60(2):148-151. doi:10.1016/ j.yhbeh.2011.04.008.

- Bartels DM: Principled moral sentiment and the flexibility of moral judgment and decision making. Cognition 2008, 108(2):381-417. doi:10. 1016/j.cognition.2008.03.001.

- Basile B et al.: Deontological and altruistic guilt: evidence for distinct neurobiological substrates. Hum Brain Mapp 2011, 32(2):229-239. doi:10. 1002/hbm.21009.

- Bellino RM: Free will in the eye of neuroscientific reductionism: the need for a philosophical foundation of moral neuropsychology. History E Philosophy of Psychology 2009, 11(1):12-16.

- Benedetti F et al.: Neural and genetic correlates of antidepressant response to sleep deprivation: a functional magnetic resonance imaging study of moral valence decision in bipolar depression. Arch Gen Psychiatry 2007, 64(2):179-187. doi:10. 1001/archpsyc.64.2.179.

- Berker S: The normative insignificance of neuroscience. Philos Public Aff 2009, 37(4):293-329. doi:10.1111/j.1088-4963.2009.01164.x.

- Berns GS, Atran S: The biology of cultural conflict. Philos Trans R Soc Lond B Biol Sci 2012, 367(1589):633-639. doi:10.1098/rstb.2011.0307.

- Berns GS et al.: Neurobiological correlates of social conformity and independence during mental rotation. Biol Psychiatry 2005, 58(3):245253. doi:10.1016/j.biopsych.2005.04.012.

- Berns GS et al.: The price of your soul: neural evidence for the non-utilitarian representation of sacred values. Philos Trans $R$ Soc Lond $B$ Biol Sci 2012, 367(1589):754-762. doi:10.1098/ rstb.2011.0262.

- Berthoz $S$ et al.: Affective response to one's own moral violations. Neuroimage 2006, 31(2):945-950. doi:10.1016/j.neuroimage.2005.12.039. 
- Berthoz S, Armony JL, Blair RJ, Dolan RJ: An fMRI study of intentional and unintentional (embarrassing) violations of social norms. Brain 2002, 125 (Pt. 8):1696-1708. doi:10.1093/brain/ awf190.

- Bertschinger N, Olbrich E, Ay N, Jost J: Autonomy: an information theoretic perspective. Biosystems 2008, 91(2):331-345.doi:10.1016/j.biosystems.2007.05. 018.

- Bird S: Ethics on the brain. Science E Spirit 2006, 17(4):65-67.

- Blair RJR: The amygdala and ventromedial prefrontal cortex in morality and psychopathy. Trends Cogn Sci 2007, 11(9):387-392. doi:10.1016/j. tics.2007.07.003.

- Blair J et al.: Neuro-cognitive systems involved in morality. Philosophical Explorations: An International Journal for the Philosophy of Mind and Action 2006, 9(1):13-27. doi:10.1080/13869790500492359.

- Boden MA: Autonomy: what is it? Introduction. Biosystems 2008, 91(2):305-308. doi:10.1016/j.biosystems.2007.07.003.

- Bok H: The implications of advances in neuroscience for freedom of the will. Neurotherapeutics 2007, 4(3):555-559. doi:10.1016/j.nurt.2007.04.001.

- Bonete E: Neuroethics in Spain: neurological determinism or moral freedom?

Neuroethics 2013, 6(1):225-232. doi:10.1007/s12152-012-9151-y.

- Borg JS et al.: Consequences, action, and intention as factors in moral judgments: an fMRI investigation. J Cogn Neurosci 2006, 18(5):803-817. doi:10.1162/jocn.2006.18.5.803.

- Borg JS, Sinnott-Armstrong W, Calhoun VD, Kiehl KA: Neural basis of moral verdict and moral deliberation. Soc Neurosci 2011, 6(4):398-413. doi:10.1080/17470919.2011.559363.

- Borg JS, Lieberman D, Kiehl KA: Infection, incest, and iniquity: investigating the neural correlates of disgust and morality. J Cogn Neurosci 2008, 20(9):1529-1546. doi:10.1162/jocn.2008.20109.

- Boyd GW: The body, its emotions, the self, and consciousness. Perspect Biol Med 2012, 55(3):362-377. doi:10.1353/pbm.2012.0031.

- Brosch T, Sander D: Neurocognitive mechanisms underlying value-based decision-making: from core values to economic value. Front Hum Neurosci 2013, 7:398. doi:10.3389/fnhum.2013.00398.

- Brosnan SF: An evolutionary perspective on morality. Journal of Economic Behavior E Organization 2011, 77(1):23-30. doi:10.1016/j.jebo.2010.04.008.
- Bruni T: Ventromedial prefrontal cortex lesions and motivational internalism. AJOB Neurosci 2012, 3(3):19-23. doi:10.1080/21507740.2012.694389.

- Bruni T: Neuroscience and moral reliability. AJOB Neurosci 2011, 2(2):15-17. doi:10.1080/21507740.2011.559913.

- Buford C, Allhoff F: Neuroscience and metaphysics. Am J Bioeth 2005, 5(2):34-36. doi:10.1080/15265160590960258.

- Buford C, Allhoff F: Neuroscience and metaphysics (redux). Am J Bioeth 2007, 7(1):58-60. doi:10.1080/15265160601064272.

- Buller T: Morality in a blur. Am J Bioeth 2008, 8(5):21-23. doi:10.1080/15265160802180018.

- Buller T: Rationality, responsibility, and brain function. Camb Q Healthc Ethics 2010, 19(2):196-204. doi:10.1017/S0963180109990466.

- Burgdorf J, Pankseep J: The neurobiology of positive emotions. Neurosci Biobehav Rev 2006, 30(2):173-187. doi:10.1016/j.neubiorev.2005.06.001.

- Burns K, Bechara A: Decision making and free will: a neuroscience perspective. Behav Sci Law 2007, 25(2):263-80. doi:10.1002/bsl.751.

- Bzdok D et al.: Parsing the neural correlates of moral cognition: ALE meta-analysis on morality, theory of mind, and empathy. Brain Struct Funct 2012, 217(4):783-796. doi:10.1007/s00429-012-0380-y.

- Cáceda R et al.: Mode of effective connectivity within a putative neural network differentiates moral cognitions related to care and justice ethics. PLoS One 2011, 6(2):e14730. doi:10.1371/ journal.pone.0014730.

- Cacioppo JT et al. Just because you're imaging the brain doesn't mean you can stop using your head: a primer and set of first principles. J Pers Soc Psychol 2003, 85(4):650-661. doi:10. 1037/0022-3514.85.4.650.

- Camps V: Neuronas y valores. Rev Neurol 2013, 57(5):230-234.

- Canli T, Amin Z: Neuroimaging of emotion and personality: scientific evidence and ethical considerations. Brain Cogn 2002, 50(3):414-431.

- Casebeer WD: Moral cognition and its neural constituents. Nat Rev Neurosci 2003, 4(10):840-846. doi:10.1038/nrn1223.

- Casebeer WD, Churchland PS: The neural mechanisms of moral cognition: a multipleaspect approach to moral judgment and decision-making. Biol Philos 2003, 18(1):169-194. doi:10.1023/A:1023380907603.

- Caspers S et al.: Moral concepts set decision strategies to abstract values. PLoS One 2011, 6(4):e18451. doi:10.1371/journal.pone.0018451. 
- Chambon V et al.: An online neural substrate for a sense of agency. Cereb Cortex 2013, 23(5):1031-1037. doi:10.1093/cercor/bhs059.

- Chaminade T, Decety J: Leader or follower? Involvement of the inferior parietal lobule in agency. Neuroreport 2002, 13(15):1975-1978. doi:10.1097/00001756-200210280-00029.

- Chang LJ, Smith A, Dufwenberg M, Sanfey AG: Triangulating the neural, psychological, and economic bases of guilt aversion. Neuron 2011, 70(3):560-572. doi:10.1016/j.neuron.2011.02.056.

- Charmetant E: Contemporary naturalism and human ontology: towards a different essentialism. Forum Philosophicum: International Journal for Philosophy 2011, 16(1):59-72.

- Check E: Ethicists urge caution over emotive power of brain scans. Nature 2005, 435(7040):254-255. doi:10.1038/435254a.

- Cheshire WP: The origami brain: from neural folds to neuroethics. Ethics Med 2011, 27(2):79-83.

- Cheshire WP: Can grey voxels resolve neuroethical dilemmas? Ethics Med 2007, 23(3):135-140.

- Chiong W: The self: from philosophy to cognitive neuroscience. Neurocase 2011, 17(3):190-200. doi:10.1080/13554794.2010.532808.

- Christensen JF, Gomila A: Moral dilemmas in cognitive neuroscience of moral decision-making: a principled review. Neurosci Biobehav Rev 2012, 36(4):1249-1264. doi:10.1016/j.neubiorev.2012.02.008.

- Churchland PM: Into the brain: where philosophy should go from here. Topoi-Int Rev Philos 2006, 25(1-2):29-32. doi:10.1007/s11245-006-0024-z.

- Churchland PS: The impact of neuroscience on philosophy. Neuron 2008, 60(3):409-411. doi:10.1016/j.neuron.2008.10.023.

- Churchland PS: Neurophilosophy: the early years and new directions. Funct Neurol 2007, 22(4):185-195.

- Churchland PS: Free will matters. AJOB Neurosci 2011, 2(3):1-2. doi:10.1080/21507740.2011.588905.

- Ciaramelli E, di Pellegrino G: Ventromedial prefrontal cortex and the future of morality. Emotion Review 2011, 3(3):308-309. doi:10.1177/ 1754073911402381.

- Ciaramelli E, Sperotto RG, Mattioli F, di Pellegrino G: Damage to the ventromedial prefrontal cortex reduces interpersonal disgust. Soc Cogn Affect Neurosci 2013, 8(2):171-180. doi:10.1093/scan/nss087.

- Ciaramidaro A, et al.: The intentional network: how the brain reads varieties of intentions. Neuropsychologia 2007, 45(13):3105-3113. doi:10.1016/j. neuropsychologia.2007.05.011.
- Cikara M, Farnsworth RA, Harris LT, Fiske ST: On the wrong side of the trolley track: neural correlates of relative social valuation. Soc Cogn Affect Neurosci 2010, 5(4):404-413. doi:10.1093/scan/nsq011.

- Claes SJ: The free brain? Tijdschr Psychiatr 2011, 53(7):389-391.

- Clark TW: Holding mechanisms responsible. Med Ethics (Burlingt Mass) 2006, 13(3):10-11.

- Cole Wright J, Cullum J, Schwab N: The cognitive and affective dimensions of moral conviction: implications for attitudinal and behavioral measures of interpersonal tolerance. Pers Soc Psychol Bull 2008, 34(11):1461-1476. doi:10.1177/ 0146167208322557.

- Conway P, Gawronski B: Deontological and utilitarian inclinations in moral decision making: a process dissociation approach. J Pers Soc Psychol 2013, 104(2):216-235. doi:10.1037/a0031021.

- Cosmides L, Tooby J, Fiddick L, Bryant GA: Detecting cheaters. Trends Cogn Sci 2005, 9(11):505-506. doi:10.1109/msp.2011.28.

- Costa AN: Images of difficulty. IIOAB Journal 2013, 4(3):3-8.

- Crockett MJ, Clark L, Hauser MD et al.: Serotonin selectively influences moral judgment and behavior through effects on harm aversion. Proc Natl Acad Sci USA 2010, 107(40):17433-17438. doi:10.1073/pnas.1009396107.

- Cromby J, Newton T, Williams SJ: Neuroscience and subjectivity. Subjectivity 2011, 4:215-226. doi:10.1057/sub.2011.13.

- Culotta E: Neuroscience. Brain stimulation sparks 'Machiavellian' choices. Science 2013, 342(6154):25. doi:10.1126/science.342.6154.25.

- Cushman F, Knobe J, Sinnott-Armstrong W: Moral appraisals affect doing/allowing judgments. Cognition 2008, 108(1):281-289. doi:10.1016/j. cognition.2008.02.005.

- Cushman F: Action, outcome, and value: a dualsystem for morality. Pers Soc Psychol Rev 2013, 17(3):273-292. doi:10.1177/1088868313495594.

- Cushman F, Young L, Hauser M: The role of conscious reasoning and intuition in moral judgment: testing three principles of harm. Psychol Sci 2006, 17(12):1082-1089. doi:10.1111/ j.1467-9280.2006.01834.x.

- Cushman F, Greene JD: Finding faults: how moral dilemmas illuminate cognitive structure. Soc Neurosci 2012, 7(3):269-279. doi:10.1080/ 17470919.2011.614000.

- Damasio A: Neuroscience and ethics: intersections. Am J Bioeth 2007, 7(1):3-7. doi:10.1080/1526516060103910. 
- da Rocha AF, Rocha FT, Massad E: Moral dilemma judgment revisited: a Loreta analysis. J Behav Brain Sci 2013, 3(8):624-640. doi:10.4236/ jbbs.2013.38066.

- da Rocha AC, Bergareche AM: Wired for autonomy. Am J Bioeth 2008, 8(5):23-25. doi:10.1080/15265160802180042.

- Dawes CT et al.: Neural basis of egalitarian behavior. Proc Natl Acad Sci 2012, 109(17):6479-6483. doi:10.1073/pnas.1118653109.

- de Achával D et al.: Activation of brain areas concerned with social cognition during moral decisions is abnormal in schizophrenia patients and unaffected siblings. $J$ Psychiatr Res 2013, 47(6):774-782. doi:10.1016/j.jpsychires.2012.12.018.

- Dean R: Does neuroscience undermine deontological theory? Neuroethics 2010, 3(1):43-60. doi:10.1007/s12152-009-9052-x.

- Decety J, Michalska KJ, Kinzler KD: The developmental neuroscience of moral sensitivity. Emot Rev 2011, 3(3):305-307. doi:10.1177/ 1754073911402373.

- Decety J, Howard LH: The role of affect in the neurodevelopment of morality. Child Dev Perspect 2013, 7(1):49-54. doi:10.1111/cdep.12020.

- Decety J, Cacioppo S: The speed of morality: a high-density electrical neuroimaging study. J Neurophysiol 2012, 108(11):3068-3072. doi:10.1152/jn.00473.2012.

- Decety J, Michalska, KJ: Neurodevelopmental changes in the circuits underlying empathy and sympathy from childhood to adulthood. Dev Sci 2010, 13(6):886-899. doi:10.1111/j.14677687.2009.00940.x.

- Decety J, Porges EC: Imagining being the agent of actions that carry different moral consequences: an fMRI study. Neuropsychologia 2011, 49(11):2994-3001. doi:10.1016/j. neuropsychologia.2011.06.024.

- Decety J: The neurodevelopment of empathy in humans. Dev Neurosci 2010, 32(4):257-267. doi:10.1159/000317771.

- Decety J, Michalska KJ, Kinzler KD: The contribution of emotion and cognition to moral sensitivity: a neurodevelopmental study. Cereb Cortex 2012, 22(1):209-220. doi:10.1093/cercor/bhr111.

- Dedeke A: A cognitive-intuitionist model of moral judgment. J Bus Ethics 2013 (online). doi:10.1007/s10551-013-1965-y.

- de Jong BM: Neurology of widely embedded free will. Cortex 2011, 47(10):1160-1065. doi:10.1016/j. cortex.2011.06.011.

- Delgado MR, Frank RH, Phelps EA: Perceptions of moral character modulate the neural systems of reward during the trust game. Nat Neurosci 2005 , 8(11):1611-1618. doi:10.1038/nn1575.

- Demirtas-Tatlidede A, Schmahmann JD: Morality: incomplete without the cerebellum? Brain 2013, 136(8):e244. doi:10.1093/brain/awt070.

- de Quervain DJ et al.: The neural basis of altruistic punishment. Science 2004, 305(5688):1254-1258. doi:10.1126/science.1100735.

- de Waal F: The animal roots of human morality. New Sci 2006, 192(2573):60-61. doi: 10.1016/ S0262-4079(06)60737-9.

- Díaz JL: The psychobiology of aggression and violence: bioethical implications. Int Soc Sci J 2010, 61(200-201):233-245. doi:10.1111/j.14682451.2011.01760.x.

- Di Francesco M, Motterlini M, Colombo M: In search of the neurobiological basis of decision making: explanation, reduction and emergence. Funct Neurol 2007, 22(4):197-204.

- Di Francesco M: Neurofilosofia, naturalismo e statuto dei giudizi morali. Etica e Politica 2007, 9(2):126-143.

- Dinh JE, Lord RG: Current trends in moral research: what we know and where to go from here. Curr Dir Psychol Sci 2013, 22(5):380-385. doi:10.1177/0963721413486147.

- Di Paolo EA, lizuka H: How (not) to model autonomous behavior. Biosystems 2008, 91(2):409-423. doi:10.1016/j.biosystems.2007.05.016.

- Drabant EM et al.: Experiential, autonomic, and neural responses during threat anticipation vary as a function of threat intensity and neuroticism. Neuroimage 2011, 55(1):401-410. doi:10.1016/j. neuroimage.2010.11.040.

- Dulac C, Rizzolatti G: Neurobiology of behavior. Curr Opin Neurobiol 2009, 19(6):634-636. doi:10.1016/j.conb.2009.10.009.

- Dupoux E, Jacob P: Universal moral grammar: a critical appraisal. Trends Cogn Sci 2007, 11(9):373-378. doi:10.1016/j.tics.2007.07.001.

- Dwyer S, Hauser MD: Dupoux and Jacob's moral instincts: throwing out the baby, the bathwater and the bathtub. Trends Cogn Sci 2008, 12(1):1-2. doi:10.1016/j.tics.2007.10.006.

- Ellemers N: Is it better to be moral than smart? The effects of morality and competence norms on the decision to work at a group status improvement. J Pers Soc Psychol 2008, 95(6):1397-1410. doi:10.1037/a0012628.

- Epstein M: Critique of moral judgment: sociology versus neuroscience. $A J O B$ Neurosci 2011, 2(2):26-28. doi:10.1080/21507740.2011.559916.

- Erickson SK, Felthous AR: Introduction to this issue: the neuroscience and psychology of moral 
decision making and the law. Behav Sci Law 2009, 27(2):119-121. doi:10.1002/bsl.858.

- Evers K: Towards a philosophy for neuroethics: an informed materialist view of the brain might help to develop theoretical frameworks for applied neuroethics. $E M B O$ Rep 2007, 8:S48-S51.

doi:10.1038/sj.embor.7401014.

- Farah MJ, Murphy N: Neuroscience and the soul. Science 2009, 323(5918):1168. doi:10.1126/ science.323.5918.1168a.

- Farah MJ, Heberlein AS: Personhood and neuroscience: naturalizing or nihilating? Am J Bioeth 2007, 7(1):37-48. doi:10.1080/15265160601064199.

- Farrer C, Frith CD: Experiencing oneself vs. another person as being the cause of an action: the neural correlates of the experience of agency. Neuroimage 2002, 15(3):596-603. doi:10.1006/ nimg.2001.1009.

- Fiddick L: Domains of deontic reasoning: resolving the discrepancy between the cognitive and moral reasoning literatures. QJ Exp Psychol A 2004, 57(3):447-474. doi:10.1080/ 02724980343000332.

- Figdor C: What is the "cognitive" in cognitive neuroscience? Neuroethics 2013, 6(1):105-114. doi:10.1007/s12152-012-9157-5.

- Figueroa G: Neuroethics: reflections on the latent principles of morals in medicine. Rev Med Chil 2012, 140(8):1078-1084. doi:10.4067/S003498872012000800018.

- Finger EC et al.: Caught in the act: the impact of audience on the neural response to morally and socially inappropriate behavior. NeuroImage 2006, 33(1):414-421. doi:10.1016/j.neuroimage.2006.06.011.

- Fins JJ: Lessons from the injured brain: a bioethicist in the vineyards of neuroscience. Camb Q Healthc Ethics 2009, 18(1):7-13. doi:10.1017/S0963180108090038.

- Fiske ST, Cuddy AJ, Glick P: Universal dimensions of social cognition: warmth and competence. Trends Cogn Sci 2007, 11(2):77-83. doi:10.1016/j. tics.2006.11.005.

- Fitzpatrick M: Can morality ever become a science? Dialogue-J Phi Sigma 54(2-3):138-154.

- Flanagan O: One enchanted being: neuroexistentialism and meaning. Zygon 2009, 44(1):41-49. doi:10.1111/j.1467-9744.2009.00984.x.

- Forbes CE, Grafman J: The role of the human prefrontal cortex in social cognition and moral judgment. Annu Rev Neurosci 2010, 33:299-324. doi:10.1146/annurev-neuro-060909-153230.

- Friedman JH: Chemical imbalance or moral weakness? Personal responsibility in a time of brain science. Med Health R I 2006, 89(3):88.
- Frost CJ, Lumia AR: The ethics of neuroscience and the neuroscience of ethics: A phenomenologicalexistential approach. Sci Eng Ethics 2012, 18(3):457-474. doi:10.1007/s11948-012-9388-1.

- Fumagalli M, Priori A: Functional and clinical neuroanatomy of morality. Brain 2012, 135(7):2006-2021. doi:10.1093/brain/awr334.

- Fumagalli $\mathrm{M}$ et al.: Conflict-dependent dynamic of subthalamic nucleus oscillations during moral decisions. Soc Neurosci 2011, 6(3):243-256. doi:10.1080/17470919.2010.515148.

- Fumagalli $M$ et al.: Gender-related differences in moral judgments. Cogn Process 2010, 11(3):219-226. doi:10.1007/s10339-009-0335-2.

- Fumagalli $\mathrm{M}$ et al.: Brain switches utilitarian behavior: does gender make a difference? PloS One 2010, 5(1):e8865. doi:10.1371/journal. pone. 0008865.

- Funayama M, Mimura M: Orbitofrontal cortex and morality. Brain and Nerve/Shinkei Kenkyu no Shinpo 2012, 64(10):1121-1129.

- Funk CM, Gazzaniga MS: The functional brain architecture of human morality. Curr Opin Neurobiol 2009, 19(6):678-681. doi:10.1016/j. conb.2009.09.011.

- Gerber B: Is there a neurobiology of the free will? EMBO Rep 2011, 13(1):17-19. doi:10.1038/ embor.2011.229.

- Gerrans P, Kennett J: Neurosentimentalism and moral agency. Mind 2010, 119(475):585-614. doi:10.1093/mind/fzq037.

- Gert B: Neuroscience and morality. Hastings Cent Rep 2012, 42(3):22-28. doi:10.1002/hast.36.

- Giligorov N: Determinism and advances in neuroscience. Virtual Mentor 2012, 14(6):489-493. doi:10.1001/virtualmentor. 2012.14.6.msoc1-1206.

- Gillett GR: The subjective brain, identity, and neuroethics. Am J Bioeth 2009 9(9):5-13. doi:10.1080/15265160903090058.

- Glannon W: Free will and moral responsibility in the age of neuroscience. Med Ethics (Burlingt Mass) 2006, 13(2):1-2.

- Gleichgerrcht $E$ et al.: The role of social cognition in moral judgment in frontotemporal dementia. Soc Neurosci 2011, 6(2):113-122. doi:10.1080/ 17470919.2010.506751.

- Glenn AL, Raine A, Schug RA: The neural correlates of moral decision-making is psychopathy. Mol Psychiatry 2009, 14(1):5-6. doi:10.1038/mp.2008.104.

- Gligorov N: Determinism and advances in neuroscience. Virtual Mentor 2012, 14(6):489-493. doi:10.1001/virtualmentor.2012.14.6.msoc1-1206. 
- Glimcher PW, Rustichini A: Neuroeconomics: the consilience of brain and decision. Science 2004, 306(5695):447-452. doi:10.1126/science.1102566.

- Gold I, Kirmayer LJ: Neuroscience as cultural intervention: reconfiguring the self as moral agent. $A J O B$ Neurosci 2010 , 1(4):53-55. doi:10.1080/21507740.2010.514884.

- Gomila A, Calvo P: Understanding brain circuits and their dynamics. Behav Brain Sci 2010, 33(4):274-275. doi:10.1017/S0140525X10001238.

- Goodenough U, Deacon TW: From biology to consciousness to morality. Zygon 2003, 38(4):801-819. doi:10.1111/j.1467-9744.2003.00540.x.

- Grahm J, Nosek BA, Haidt J, IyerR et al.: Mapping the moral domain. J Pers Soc Psychol 2011, 101(2):366-385. doi:10.1037/a0021847.

- Green S et al.: Selective functional integration between anterior temporal and distinct frontomesolimbic regions during guilt and indignation. Neuroimage 2010, 52(4):1720-1726. doi:10.1016/j. neuroimage.2010.05.038.

- Greene JD et al.: The neural bases of cognitive conflict and control in moral judgment. Neuron 2004, 44(2):389-400. doi:10.1016/j.neuron.2004.09.027.

- Greene JD et al.: Cognitive load selectively interferes with utilitarian moral judgment. Cognition 2008, 107(3):1144-1154. doi:10.1016/j.cognition.2007.11.00.4.

- Greene J: Opinion: from neural 'is' to moral 'ought': what are the moral implications of neuroscientific moral psychology? Nat Rev Neurosci 2003, 4:846-850. doi:10.1038/nrn1224.

- Greene J, Haidt J: How (and where) does moral judgment work? Trends Cog Sci 2002, 6(12):517-523. doi:10.1016/s1364-6613(02)02011-9.

- Greene JD: Emotion and morality: A tasting menu. Emot Rev 2011, 3(3):1-3. doi:10.1177/ 1754073911409629.

- Greene JD: Why are VMPFC patients more utilitarian? A dual-process theory of moral judgment explains. Trends Cogn Sci 2007, 11(8):322-323. doi:10.1016/j.tics.2007.06.004.

- Greene JD: Dual-process morality and the personal/impersonal distinction: a reply to McGuire, Langdon, Coltheart, and Mackenzie. J Exp Soc Psychol 2009, 45(3):581-584. doi:10.1016/j.jesp.2009.01.003.

- Greene JD et al.: Pushing moral buttons: the interaction between personal force and intention in moral judgment. Cognition 2009, 111(3):364371. doi:10.1016/j.cognition.2009.02.001.

- Greenspan RJ: Biological indeterminacy. Sci Eng Ethics 2012, 18(3):447-452. doi:10.1007/s11948012-9379-2.
- Güroğlu B, van den Bos W, Rombouts SA, Crone EA: Unfair? It depends: a neural correlates of fairness in social context. Soc Cogn Affect Neurosci 2010, 5(4):414-423. doi:10.1093/scan/nsq013.

- Haidt J, Morris JP: Finding the self in selftranscendent emotions. Proc Natl Acad Sci USA 2009, 106(19):7687-7688. doi:10.1073/ pnas.0903076106.

- Haidt J: The new synthesis in moral psychology. Science 2007, 316(5827):998-1002. doi:10.1126/ science.1137651.

- Haidt J, Joseph C: Intuitive ethics: how innately prepared intuitions generate culturally variable virtues. Daedalus 2004, 133(4):55-66. doi:10.1162/ 0011526042365555.

- Haidt J: Morality. Perspect Psychol Sci 2008, 3(1):65-72. doi:10.1111/j.1745-6916.2008.00063.x.

- Harenski CL, Antonenko O, Shane MS, Kiehl KA: Gender differences in neural mechanisms underlying moral sensitivity. Soc Cogn Affect Neurosci 2008, 3(4):313-321. doi:10.1093/scan/ nsn026.

- Harenski CL, Hamann S: Neural correlates of regulating negative emotions related to moral violations. Neuroimage 2006, 30(1):313-324. doi:10.1016/j.neuroimage.2005.09.034.

- Harenski CL, Antonenko O, Shane MS, Kiehl KA: A functional imaging investigation of moral deliberation and moral intuition. Neuroimage 2010, 49(3):2707-2716. doi:10.1016/j.neuroimage. 2009.10.062.

- Hayashi A et al.: Neural correlates of forgiveness for moral transgressions involving deception. Brain Res 2010, 1332:90-99. doi:10.1016/j. brainres.2010.03.045.

- Häyry M: Neuroethical theories. Camb Q Healthc Ethics 2010, 19(2):165-178. doi:10.1017/ S0963180109990430.

- Heekeren HR et al.: Influence of bodily harm on neural correlates of semantic and moral decision-making. Neuroimage 2005, 24(3):887-897. doi:10.1016/j.neuroimage.2004.09.026.

- Heekeren HR et al.: An fMRI study of simple ethical decision-making. Neuroreport 2003, 14(9):1215-1219. doi:10.1097/00001756200307010-00005.

- Heinzelmann N, Ugazio G, Tobler PN: Pragmatic implications of empirically studying moral decision-making. Front Neurosci 2012, 6:94. doi:10.3389/fnins.2012.00094.

- Hsu M, Anen C, Quartz SR: The right and the good: distributive justice and neural encoding of equity and efficiency. Science 2008, 320 (5879):1092-1095. doi:10.1126/science.1153651. 
- Ikegami T, Suzuki K: From a homeostatic to homeodynamic self. Biosystems 2008, 91(2):388400. doi:10.1016/j.biosystems.2007.05.014.

- Illes J: Empirical neuroethics: can brain imaging visualize human thought? Why is neuroethics interested in such a possibility? EMBO Rep 2007, 8(Suppl 1):S48-S51. doi:10.1038/sj.embor.7401007.

- Jack AI, Dawson AJ, Norr ME: Seeing human: distinct and overlapping neural signatures associated with two forms of dehumanization. Neuroimage 2013, 79:313-328. doi:10.1016/j. neuroimage.2013.04.109.

- Jedlicka P: Neuroethics, reductionism, and dualism. Trends Cogn Sci 2005, 9(4):172. doi:10.1016/j.tics.2005.02.010.

- Jirsa J: Morality as a science? Filos Cas 2013, 61(4):581-590.

- Júnior RM: Neuroética: o cérebro como órgão da ética e da moral. Revista Bioética 2010, 18(1):109-120.

- Kahane G et al.: The neural basis of intuitive and counterintuitive moral judgment. Soc Cogn Affect Neurosci 2012, 7(4):393-402. doi:10.1093/ scan/nsr005.

- Kahane G, Shackel N: Methodological issues in the neuroscience of moral judgment. Mind Lang 2010, 25(5):561-582. doi:10.1111/j.14680017.2010.01401.x.

- Kahn PH Jr: Mind and morality. New Dir Child Adolesc Dev 2004, 103:73-83. doi:10.1002/cd.99.

- Kamm FM: Neuroscience and moral reasoning: a note on recent research. Philos Public Aff 2009, 37(4):330-345. doi:10.1111/j.10884963.2009.01165.x.

- Kaposy C: Will neuroscientific discoveries about free will and selfhood change our ethical practices? Neuroethics 2009, 2(1):51-59. doi:10.1007/s12152-008-9020-x.

- Karlsson H: Psychiatry, neuroscience and free will. Nord J Psychiatry 2005, 59(1):5. doi:10.1080/ 08039480510018869.

- Kaufman WRP: Can science determine moral values? a reply to Sam Harris. Neuroethics 2012, 5(1):55-65. doi:10.1007/s12152-010-9096-y.

- Kauppinen A: Moral internalism and the brain. Soc Theory Pract 2008, 34(1):1-24. doi:10.5840/ soctheorpract20083411.

- Kawohl W, Habermeyer E: Free will: reconciling German civil law with Libet's neuropsychological studies on the readiness potential. Behav Sci Law 2007, 25(2):309-320. doi:10.1002/bsl.752.

- Keller M, Gummerum M, Wang XT, Lindsey S: Understanding perspectives and emotions in contract violation: development of deontic and moral reasoning. Child Dev 2004, 75(2):614-635. doi:10.1111/j.1467-8624.2004.00696.x.

- Killen M, Smetana J: Moral judgment and moral neuroscience: intersections, definitions, and issues. Child Dev Perspect 2008, 2(1):1-6. doi:10.1111/j.1750-8606.2008.00033.x.

- Killen $\mathrm{M}$ et al.: The accidental transgressor: morally-relevant theory of mind. Cognition 2011, 119(2):197-215. doi:10.1016/j. cognition.2011.01.006.

- Killen M, Smetana J: The biology of morality: human development and moral neuroscience. Human Development 2007, 50(5):241-243. doi:10.1159/000106413.

- Kittay EF: At the margins of moral personhood. Ethics 2005, 116(1):100-131. doi:10.1086/454366.

- Klosterkötter J: Subjective experience and neuroscience. Fortschr Neurol Psychiatr 2006, 74(11):619-620. doi:10.1055/s-2006-944286.

- Knabb JJ, Welsh RK, Ziebell JG, Reimer KS: Neuroscience, moral reasoning, and the law. Behav Sci Law 2009, 27(2):219-236. doi:10.1002/ bsl.854.

- Knobe J: Theory of mind and moral cognition: exploring the connections. Trends Cogn Sci 2005, 9(8):357-359. doi:10.1016/j.tics.2005.06.011.

- Koenigs $M$ et al.: Damage to the prefrontal cortex increases utilitarian moral judgments. Nature 2007, 446(7138):908-911. doi:10.1038/ nature05631.

- Koenigs M: The neuropsychology of disgust. Soc Cogn Affect Neurosci 2013, 8(2):121-122. doi:10.1093/scan/nss134.

- Koscik TR, Tranel D: The human amygdala is necessary for developing and expressing normal interpersonal trust. Neuropsychologia 2011, 49(4):602-611. doi:10.1016/j. neuropsychologia.2010.09.023.

- Kosfeld $M$ et al.: Oxytocin increases trust in human. Nature 2005, 435(7042):673-676. doi:10.1038/nature03701.

- Koster-Hale J, Saxe R, Dungan J, Young LL: Decoding moral judgments from neural represents of intentions. Proc Natl Acad Sci USA 2013, 110(14):5648-5653. doi:10.1073/ pnas.1207992110.

- Krawczyk DC: Contributions of the prefrontal cortex to the neural basis of human decision making. Neurosci Biobehav Rev 2002, 26(6):631664. doi:10.1016/S0149-7634(02)00021-0.

- Krebs DL, Denton K:Explanatory limitations of cognitive-developmental approaches to morality. Psychol Rev 2006, 113(3):672-675. doi:10.1037/ 0033-295x.113.3.672. 
- Kvaran T, Nichols S, Sanfey A: The effect of analytic and experiential modes of thought on moral judgment. Prog Brain Res 2013, 202:187196. doi:10.1016/B978-0-444-62604-2.00011-3.

- Kvaran T, Sanfey AG: Toward an integrated neuroscience of morality: the contribution of neuroeconomics to moral cognition. Top Cog Sci 2010, 2(3):579-595.doi:10.1111/j.17568765.2010.01086.x.

- Lahat A, Helwig CC, Zelazo PD: An event-related potential study of adolescents' and young adults' judgments of moral and social conventional violations. Child Dev 2013, 84(3):955-969. doi:10.1111/cdev.12001.

- Lampe M: Science, human nature, and a new paradigm for ethics education. Sci Eng Ethics 2012, 18(3):543-549. doi:10.1007/s11948-012-9373-8.

- Lane JD, Wellman HM, Olson SL, LaBounty J, Kerr DC: Theory of mind and emotion understanding predict moral development in early childhood. Br J Dev Psychol 2010, 28(4):871-889. doi:10.1348/ $026151009 \times 483056$.

- Leben D: Cognitive neuroscience and moral decision-making: guide or set aside? Neuroethics 2011, 4(2):163-174. doi:10.1007/s12152-010-9087-z.

- Lee W, Reeve J: Self-determined, but not nonself-determined, motivation predicts activations in the anterior insular cortex: an fMRI study of personal agency. Soc Cogn Affect Neurosci 2013, 8(5):538-545. doi:10.1093/scan/nss029.

- Legault L, Inzlicht M: Self-determination, selfregulation, and the brain: autonomy improves performance by enhancing neuroaffective re sponsiveness to self-regulation failure. $J$ Pers Soc Psychol 2013, 105(1):123-138. doi:10.1037/ a0030426.

- Lev O: Enhancing the capacity for moral agency. AJOB Neurosci 2012, 3(4):20-22. doi:10.1080/ 21507740.2012.721462.

- Levy DA: Neural holism and free will. Philos Psychol 2003, 16(2):205-228. doi:10.1080/ 09515080307765.

- Levy N: Cognitive scientific challenges to morality. Philos Psychol 2006, 19(5):567-587. doi:10.1080/09515080600901863.

- Levy N: Empirically informed moral theory: a sketch of the landscape. Ethical Theory Moral Pract 2009, 12(1):3-8. doi:10.1007/s10677-0089146-2.

- Levy N: Rethinking neuroethics in the light of the extended mind thesis. Am J Bioeth 2007, 7(9):3-11. doi:10.1080/15265160701518466.

- Lewis GJ, Kanai R, Bates TC, Rees G: Moral values are associated with individual differences in regional brain volume. J Cogn Neurosci 2012, 24(8):1657-1663. doi:10.1162/jocn_a_00239.

- Li P, Jia S, Feng T, Liu Q, Suo T, Li H: The influence of the diffusion of responsibility effect on outcome evaluations: electrophysiological evidence from an ERP study. Neuroimage 2010, 52(4):1727-1733. doi:10.1016/j. neuroimage.2010.04.275.

- Longuenesse B: "I" and the brain. Psychol Res 2012, 76(2):220-228. doi:10.1007/s00426-0110382-z.

- Loye D: The moral brain. Brain and Mind 2002, 3(1):133-150. doi:10.1023/A:1016561925565.

- Lunstroth J, Goldman J: Ethical intelligence from neuroscience: is it possible? AJOB 2007, 7(5):18-20. doi:10.1080/15265160701290280.

- Lunstroth J: No strangers: medicine, neuroscience, and philosophy. Am J Bioeth 2008, 8(1):59-61. doi:10.1080/15265160701839680.

- Luo Q et al.: The neural basis of implicit moral attitude-an IAT study using event-related MRI. Neuroimage 2006, 30(4):1449-1457. doi:10.1016/j. neuroimage.2005.11.005.

- Majdandžić J et al.: The human factor: behavioral and neural correlates of humanized perception in moral decision making. PLoS One 2012, 7(10): e47698. doi:10.1371/journal.pone.0047698.

- Malti T, Gummerum M, Keller M: Moral emotions and moral cognitions. Int J Dev Sci 2008, 2(3):203-205. doi:10.3233/DEV-2008-2301.

- Margoni F: Dilemmi e scelte morali, oltre Greene? BrainFactor 2013, 5(3):005.

- Margoni F: Emozioni diverse per giudizi morali diversi? BrainFactor 2013, 5(4):010.

- Margoni F: Fattori irrilevanti e giudizio morale. BrainFactor 2013, 5(2):006.

- Markic O: Nevroetika: vprasanje moralne odgovornosti. Casopis za Kritiko Znanosti 2011, 39(246):15-25, 223, 229.

- McClelland RT: The pleasures of revenge. Journal of Mind and Behavior 2010, 31(3-4):195-235.

- McGoldrick TA: The spirituality of human consciousness: a Catholic evaluation of some current neuro-scientific interpretations. Sci Eng Ethics 2012, 18(3):483-501. doi:10.1007/s11948012-9387-2.

- McGuire J, Langdon R, Coltheart M, Mackenzie C: A reanalysis of the personal/impersonal distinction in moral psychology research. J Exp Soc Psychol 2009, 45(3):581-584.

- McKaughan DJ: Voles, vasopressin, and infidelity: a molecular basis for monogamy, a platform for ethics, and more? Biol Philos 2012, 27(4):521-543. doi:10.1007/s10539-011-9303-1. 
- Meeks TW, Jeste DV: Neurobiology of wisdom: a literature overview. Arch Gen Psychiatry 2009, 66(4):355-365. doi:10.1001/archgenpsychiatry.2009.8.

- Mele A: Free will and neuroscience. Philos Exch 2013, 43(1):3. http://digitalcommons.brockport.edu/ phil_ex/vol43/iss1/3.

- Mele A: Unconscious decisions and free will. Philos Psychol 2013, 26(6):777-789. doi:10.1080/ 09515089.2012.724395.

- Meloni M: Moralizing biology: the appeal and limits of the new compassionate view of nature. Hist Human Sci 2013, 26(3):82-106. doi:10.1177/ 0952695113492163.

- Mende-Siedlecki P, Baron SG, Todorov A: Diagnostic value underlies asymmetric updating impressions in the morality and ability domains. J Neurosci 2013, 33(50):19406-19415. doi:10.1523/ jneurosci.2334-13.2013.

- Mendez MF: The neurobiology of moral behavior: review and neuropsychiatric implications. CNS Spectr 2009, 14(11):608-620.

- Mercadillo RE, Arias NA: Violence and compassion: a bioethical insight into their cognitive bases and social manifestations. Int Soc Sci J 2010, 61(200-201):221-232. doi:10.1111/ j.1468-2451.2011.01759.x.

- Mercadillo RE, Diaz JL, Barrios FA: Neurobiología de las emociones morales. Salud Ment (Mex) 2007, 30(3):1-11.

- Mikhail J: Universal moral grammar: theory, evidence, and the future. Trends Cogn Sci 2007, 11(4):143-152. doi:10.1016/j.tics.2006.12.007.

- Mikhail J: Emotion, neuroscience, and law: A comment on Darwin and Greene. Emot Rev 2011, 3(3):293-295.doi:10.1177/1754073911406150.

- Miller G: The roots of morality. Science 2008, 320 (5877):734-737. doi:10.1126/science.320.5877.734.

- Mimura M: Role of orbitofrontal cortex in moral judgment. Rinsho Shinkeigaku 2010, 50(11):10071009. doi:10.5692/clinicalneurol.50.1007.

- Mirabella G: Endogenous inhibition and the neural basis of "free won't." J Neurosci 2007, 27(51):13919-13920. doi:10.1523/jneurosci.494307.2007.

- Mograbi GJC: Neurophilosophical considerations on decision making: pushing-up the frontiers without disregarding their foundations. Front Neurosci 2013, 7: 261. doi:10.3389/fnins.2013.00261.

- Moll J, Schulkin J: Social attachment and aversion in human moral cognition. Neurosci Biobehav Rev 2009, 33(3):456-465. doi:10.1016/j. neubiorev.2008.12.001.

- Moll J, De Oliveira-Souza R, Zahn R: The neural basis of moral cognition: sentiments, concepts, and values. Ann N Y Acad Sci 2008, 1124:161-180. doi:10.1196/annals.1440.005.

- Moll J et al.: The moral affiliations of disgust: a functional MRI study. Cogn Behav

Neurol 2005, 18(1):68-78. doi:10.1097/01. wnn.0000152236.46475.a7.

- Moll J, de Oliveira-Souza R: Moral judgments, emotions and the utilitarian brain. Trends Cogn Sci 2007, 11(8):319-321. doi:10.1016/j. tics.2007.06.001.

- Moll J, de Oliveira-Souza R, Eslinger PJ: Morals and the human brain: a working model. Neuroreport 2003, 14(3):299-305. doi:10.1097/00001756200303030-00001.

- Moll J, Schulkin J. Social attachment and aversion in human moral cognition. Neurosci Biobehav Rev 2009, 33(3):456-465. doi:10.1016/j. neubiorev.2008.12.001.

- Moll J, De Oliveira-Souza R: When morality is hard to like. Sci Am Mind 2008, 19(1):30-35. doi:10.1038/scientificamericanmind0208-30.

- Moll J, de Oliveira-Souza R, Bramati IE, Grafman J: Functional networks in emotional moral and nonmoral social judgments. Neuroimage 2002, 16(3):696-703. doi:10.1006/nimg.2002.1118.

- Moll J et al.: The neural correlates of moral sensitivity: a functional magnetic resonance imaging investigation of basic and moral emotions. J Neurosci 2002, 22(7):2730-2736. doi:10.1001/archpsyc.64.2.179.

- Moll J et al.: Opinion: the neural basis of human moral cognition. Nat Rev Neurosci 2005, 6(10):799-809. doi:10.1038/nrn1768.

- Moll J et al.: The self as a moral agent: link-ling the neural bases of social agency and moral sensitivity. Soc Neurosci 2007, 2(3-4):336-352. doi:10.1080/17470910701392024.

- Moran JM et al.: Impaired theory of mind for moral judgment in high-functioning autism. Proc Natl Acad Sci USA 2011, 108(7):2688-2692. doi:10.1073/pnas.1011734108.

- Moreno A, Etxeberria A, Umerez J: The autonomy of biological individuals and artificial models. Biosystems 2008, 91(2):309-319. doi:10.1016/j. biosystems.2007.05.009.

- Moreno J: Society and the reception of imaging technology: the American experience. Cortex 2011, 47(10):1256-1258. doi:10.1016/j. cortex.2011.04.024.

- Moretto G, Làdavas E, Mattioli F, di Pellegrino G: A psychophysiological investigation of moral judgment after ventromedial prefrontal damage. J Cogn Neurosci 2010, 22(8):1888-1899. doi:10.1162/jocn.2009.21367. 
- Morris SG: Neuroscience and the free will conundrum. Am J Bioeth 2007, 7(5):20-22. doi:10.1080/15265160701290298.

- Morrison NK, Severino SK: Toward a biological framework for morality. NeuroQuantology 2005, 3(4). doi:10.14704/nq.2005.3.4.78.

- Moya CJ: Libertad, responsabilidad moral y neurociencia. Pasajes: Revista de Pensamiento Contemporaneo 2012, 37:109-118.

- Mulert C et al.: Evidence for a close relationship between conscious effort and anterior cingulate cortex activity. Int J Psychophysiol 2005, 56(1):65-80. doi:10.1016/j.ijpsycho.2004.10.002.

- Müller S, Walter H: Review autonomy: Implications of the neurosciences and the free will debate for the principle of respect for the patient's autonomy. Camb Q Healthc Ethics 2010, 19(2):205-217. doi:10.1017/s0963180109990478.

- Murphy FC et al.: Assessing the automaticity of moral processing: efficient coding of moral information during narrative comprehension. QJ Exp Psychol (Hove) 2009, 62(1):41-49. doi:10.1080/ 17470210802254441.

- Murphy N: Whatever happened to the soul? Theological perspectives on neuroscience and the self. Ann NY Acad Sci 2003, 1001:51-64. doi:10.1196/annals.1279.004.

- Myyry L, Helkama K: Socio-cognitive conflict, emotions, and complexity of thought in real-life morality. Scand J Psychol 2007, 48(3):247-259. doi:10.1111/j.1467-9450.2007.00579.x.

- Nahab FB et al.: The neural processes underlying self-agency. Cereb Cortex 2011, 21(1):48-55. doi:10.1093/cercor/bhq059.

- Nahra C: Neuroscience of ethics: the state of art and the promises for the future. Ethic@Revista Internacional de Filosofia da Moral 2011, 10 (1):109-132. doi:10.5007/1677-2954.2011v10n1p109.

- Nakao H, Itakura S: An integrated view of empathy: psychology, philosophy, and neuroscience. Integr Psychol Behav Sci 2009 , 43(1):42-52. doi:10.1007/s12124-008-9066-7.

- Nakao T, Ohira H, Northoff G: Distinction between externally vs. internally guided decision-making: operational differences, meta-analytical comparisons and their theoretical implications. Front Neurosci 2012, 6:31. doi:10.3389/fnins.2012.00031.

- Narvaez D: Triune ethics: the neurobiological roots of our multiple moralities. New Ideas Psychol 2008, 26(1):95-119.

- Narvaez D, Vaydich JL: Moral development and behaviour under the spotlight of the neurobiological sciences. J Moral Educ 2008, 37(3):289-312. doi:10.1080/03057240802227478.

- Nau JY:Submissive mind exploration of ethical questions. Rev Med Suisse 2008, 4(152):935.

- Nicolle A, Bach DR, Frith C, Dolan RJ: Amygdala involvement in self-blame regret. Soc Neurosci 2011, 6(2):178-189. doi:10.1080/17470919.2010.506128.

- Northoff G: Neuroscience of decision making and informed consent: an investigation in neuroethics. J Med Ethics 2006, 32(2):70-73. doi:10.1136/jme.2005.011858.

- Northoff G, Boeker H, Bogerts B: Subjective experience and neuronal integration in the brain: do we need a first-person neuroscience? Fortschr Neurol Psychiatr 2006, 74(11):627-634. doi:10.1055/s-2005-915610.

- Overman W et al.: Contemplation of moral dilemmas eliminates sex differences on the Iowa gambling task. Behav Neurosci 2006, 120(4):817-825. doi:10.1037/0735-7044.120.4.817.

- Parkinson $C$ et al.: Is morality unified? Evidence that distinct neural systems underlie moral judgments of harm, dishonesty, and disgust. J Cogn Neurosci 2011, 23(10):3162-3180. doi:10.1162/jocn_a_00017.

- Pascual L, Rodrigues P, Gallardo-Pujol D: How does morality work in the brain? A functional and structural perspective of moral behavior. Front Integr Neurosci 2013, 7:65. doi:10.3389/ fnint.2013.00065.

- Passos-Ferreira C: Seria a moralidade determinada pelo cerebro? Neuronios-espelhos, empatia e neuromoralidade. [Does the brain have anything to do with morality? Mirror neurons, empathy and neuromorality]. Physis 2011, 21(2):471-490.

- Pastötter B, Gleixner S, Neuhauser T, Bäuml KH: To push or not to push? Affective influences on moral judgment depend on decision frame. Cognition 2013, 126(3):373-377. doi:10.1016/j. cognition.2012.11.003.

- Patterson R, Rothstein J, Barbey AK: Reasoning, cognitive control, and moral intuition. Front Integr Neurosci 2012, 6:114. doi:10.3389/ fnint.2012.00114.

- Pfaff DW, Kavaliers M, Choleris E: Mechanisms underlying an ability to behave ethically. Am J Bioeth 2008, 8(5):10-19. doi:10.1080/ 15265160802179994.

- Phelps EA: The neuroscience of a person network. Am J Bioeth 2007, 7(1):49-50. doi:10.1080/15265160601064223.

- Pockett S: The concept of free will: philosophy, neuroscience and the law. Behav Sci Law 2007, 25(2):281-293. doi:10.1002/bsl.743. 
- Powell R: The biomedical enhancement of moral status. J Med Ethics 2013, 39(2):65-66. doi:10.1136/medethics-2012-101312.

- Prehn $\mathrm{K}$ et al.: Individual differences in moral judgment competence influence neural correlates of socio-normative judgments. Soc Cogn Affect Neurosci 2008, 3(1):33-46. doi:10.1093/scan/nsm037.

- Preston JL, Ritter RS, Hepler J: Neuroscience and the soul: competing explanations for the human experience. Cognition 2013, 127(1):31-37. doi:10.1016/j.cognition.2012.12.003.

- Price JL: Free will versus survival: brain systems that underlie intrinsic constraints on behavior. J Comp Neurol 2005, 493(1):132-139. doi:10.1002/ cne.20750.

- Prinz J: The emotional basis of moral judgments. Philos Explor 2006, 9(1):29-43. doi:10.1080/ 13869790500492466.

- Pyysiäinen I, Hauser M: The origins of religion: evolved adaptation or by-product? Trends Cogn Sci 2010, 14(3):104-109. doi:10.1016/j. tics.2009.12.007.

- Radman Z: The ethical mind: an outline. Synth Philos 2006, 21(2):385-394.

- Raine A, Yang Y: Neural foundations to moral reasoning and antisocial behavior. Soc Cogn Affect Neurosci 2006, 1(3):2-3-213. doi:10.1093/ scan/nsl03.3.

- Rapley M, McCarthy D, McHoul A: Mentality or morality? Membership categorization, multiple meanings and mass murder. Br J Soc Psychol 2003, 42(3):427-444. doi:10.1348/014466603322438242.

- Rasmusson A: Neuroethics as a brain-based philosophy of life: the case of Michael S. Gazzaniga. Neuroethics 2009, 2(1):3-11. doi:10.1007/s12152008-9024-6.

- Ravven HM: Spinoza's anticipation of contemporary affective neuroscience. Consciousness E Emotion 2003, 4(2):257-290.

- Reichlin M: The challenges of neuroethics. Funct Neurol 2007, 22(4):219-234.

- Rengifo FJ: "La responsabilidad del sujeto". Desde el Jardin de Freud 2005, 5:144-155.

- Reniers RL et al.: Moral decision-making, ToM, empathy and the default mode network. Biol Psychol 2012, 90(3):202-210. doi:10.1016/j. biopsycho.2012.03.009.

- Reynolds SJ: A neurocognitive model of the ethical decision-making process: implications for study and practice. J Appl Psychol 2006, 91(4):737-748. doi:10.1037/0021-9010.91.4.737.

- Rilling JK et al.: A neural basis for social cooperation. Neuron 2002, 35(2):395-405. doi:10.1016/S0896-6273(02)00755-9.
- Robertson D et al.: The neural processing of moral sensitivity to issues of justice and care. Neuropsychologia 2007, 45(4):755-766. doi:10.1016/ j.neuropsychologia.2006.08.014.

- Robinson DN: Big brains and Boskops: phrenology lives! Theory Psychol 2013, 23(3):391396. doi:10.1177/0959354312471741.

- Rockwell T: Where should we look for mental representations? On the need for epistemic ethics. Account Res 2013, 20(1):42-56. doi:10.1080/ 08989621.2013 .749746$.

- Rohde M, Stewart J: Ascriptional and 'genuine' autonomy. Biosystems 2008, 91(2):424-433. doi:10.1016/j.biosystems.2007.05.017.

- Rose N: Screen and intervene: governing risky brains. Hist Human Sci 2010, 23(1):79-105. doi:10.1177/0952695109352415.

- Roskies AL: Neuroscientific challenges to free will and responsibility. Trends Cogn Sci 2006, 10(9):419-423. doi:10.1016/j.tics.2006.07.011.

- Roskies AL: How does the neuroscience of decision making bear on our understanding of moral responsibility and free will? Curr Opin Neurobiol 2012, 22(6):1022-1026. doi:10.1016/j. conb.2012.05.009.

- Roskies, AL: Response to Sie and Wouters: a neuroscientific challenge to free will and responsibility? Trends Cogn Sci 2008, 12(1):4. doi:10.1016/j.tics.2007.10.003.

- Roskies AL: A puzzle about empathy. Emot Rev 2011, 3(3):278-280. doi:10.1177/1754073911402395.

- Roskies A: Are ethical judgments intrinsically motivational? Lessons from "acquired sociopathy". Philos Psychol 2003, 16(1):51-66. doi:10.1080/0951508032000067743.

- Rubia-Vila FJ. The ghost of the free will. $A n R$ Acad Nac Med (Madr) 2009, 126(3):377-387.

- Sandberg J, Juth N: Ethics and intuitions: a reply to Singer. J Ethics 2011, 15(3):209-226. doi:10.1007/s10892-010-9088-5.

- Sarlo M et al.: Temporal dynamics of cognitiveemotional interplay in moral decision-making. J Cogn Neurosci 2012, 24(4):1018-1029. doi:10.1162/jocn_a_00146.

- Schaefer GO: What is the goal of moral engineering? AJOB Neurosci 2011, 2(4):10-11. doi:10.1080/21507740.2011.620593.

- Schleim S, Schirmann F: Philosophical implications and multidisciplinary challenges of moral physiology. TRAMES-J Humanit Soc 2011, 15(2):127-146. doi:10.3176/tr.2011.2.02.

- Schleim S: Moral physiology, its limitations and philosophical implications. Jahr Wiss Ethik 2008, 13:51-80. 
- Schirmann F: Invoking the brain in studying morality: a theoretical and historical perspective on the neuroscience of morality. Theory Psychol 2013, 23(3):289-304. doi:10.1177/ 0959354313478479.

- Schoenherr-Mann HM: Willensfreiheit und Verantwortung zwischen Philosophie und Hirnforschung [Free will and responsibility between philosophy and brain research]. Ethica 2012, 20(3):237-253.

- Seok B: Neuroscience, moral sentimentalism, and Confucian philosophy: moral psychology of the body and emotion. APA Newsl: Asian Phil 2013, 13(1):2-9.

- Severino SK: Free will according to John Duns Scotus and neuroscience. Zygon 2012, 47(1):156174. doi:10.1111/j.1467-9744.2011.01244.x.

- Shadlen MN, Roskies AL: The neurobiology of decision-making and responsibility: reconciling mechanism and mindedness. Front Neurosci 2012, 6:56. doi:10.3389/fnins.2012.00056.

- Shalvi S, Eldar O, Bereby-Meyer Y: Honesty requires time (and lack of justifications). Psychol Sci 2012, 23(10):1264-1270. doi:10.1177/ 0956797612443835.

- Shenhav A, Greene JD: Moral judgments recruit domain-general valuations mechanisms to integrate representations of probability and magnitude. Neuron 2010, 67(4):667-677. doi:10.1016/j. neuron.2010.07.020.

- Shermer M: The science of right and wrong. Can data determine moral values? Sci Am 2011, 304(1):83.

- Shoemaker WJ: The social brain network and human moral behavior. Zygon 2012, 47(4):806820. doi:10.1111/j.1467-9744.2012.01295.x.

- Sie M, Wouters A: The BCN challenge to compatibilist free will and personal responsibility. Neuroethics 2010, 3(2):121-133. doi:10.1007/s12152-009-9054-8.

- Sie M, Wouters A: The real challenge to free will and responsibility. Trends Cogn Sci 2008, 12(1):3-4. doi:10.1016.j.tics.2007.10.005.

- Sie M: Moral agency, conscious control, and deliberative awareness. Inquiry 52(5):516-531. doi:10.1080/00201740903302642

- Siegal M, Varley R: Neural systems involved in "theory of mind." Nat Rev Neurosci 2002, 3(6):463-471. doi:10.1038/nrn844.

- Singer P: Ethics and intuitions. J Ethics 2005, 9(3-4):331-352. doi:10.1007/s10892-005-3508-y.

- Singer T et al.: Empathic neural responses are modulated by the perceived fairness of others. Nature 2006, 439(7075):466-469. doi:10.1038/ nature04271.
- Singer $\mathrm{T}$ et al.: Brain responses to the acquired moral status of faces. Neuron 2004, 41(4):653662. doi:10.1016/s0896-6273(04)00014-5.

- Singer T: The neuronal basis of empathy and fairness. Novartis Found Symp 2007, 278:20-30.

- Sinnott-Armstrong W: Does morality have an essence? Psychol Inq 2012, 23(2):194-197. doi:10.1080/1047840x.2012.666653.

- Sinnott-Armstrong W, Wheatley T: The disunity of morality and why it matters to philosophy. The Monist 2012, 95(3):355-377. doi:10.5840/ monist201295319.

- Slachevsky A, Silva JR, Prenafeta ML, Novoa F: The contribution of neuroscience to the understanding of moral behavior. Rev Med Chil 2009, 137(3):419-425. doi:/S003498872009000300015.

- Slingerland E: "Of what use are the odes?" cognitive science, virtue ethics, and early Confucian ethics. Philos East West 2011, 61(1):80-109.

- Smetana JG, Killen M: Moral cognition, emotions, and neuroscience: An integrative developmental view. International Journal of Developmental Science 2008, 2(3):324-339. doi:10.3233/DEV2008-2309.

- Smith K: Neuroscience vs. philosophy: taking aim at free will. Nature 2011, 477(7362):23-25. doi:10.1038/477023a.

- Smith MJ: Conceptualizing the "self" in neuroethics: an appeal to philosophy of mind. AJOB Neurosci 2010, 1(3):16-17. doi:10.1080/ 21507740.2010 .485271$.

- Sokol BW, Chandler MJ, Jones C: From mechanical to autonomous agency: the relationship between children's moral judgments and their developing theories of mind. New Dir Child Adolesc Dev 2004, 103:19-36. doi:10.1002/cd.95.

- Sommer M et al.: How should I decide? the neural correlates of everyday moral reasoning. Neuropsychologia 2010, 48(7):2018-2026. doi:10.1016/j.neuropsychologia.2010.03.023.

- Sousa P, Holbrook C, Piazza J: The morality of harm. Cognition 2009, 113(1):80-92. doi:10.1016/j. cognition.2009.06.015.

- Spezio M: The neuroscience of emotion and reasoning in social contexts: implications for moral theology. Mod Theol 2011, 27(2):339-356. doi:10.1111/j.1468-0025.2010.01680.x.

- Suhler CL, Churchland P: Can innate, modular "foundations" explain morality? challenges for Haidt's moral foundations theory. J Cogn Neurosci 2011, 23(9):2103-2116. doi:10.1162/ jocn.2011.21637. 
- Tachiki N: A natural science approach to the study of morality: recent developments in the study of morality through the cooperation between cognitive neuroscience and evolutionary biology. Studies in Moralogy: The Forum for Ethical and Moral Studies, 2013, 71:39-49.

- Takala T, Buller T: Neural grafting: implications for personal identity and personality. TRAMES-J Humanit Soc, 2011, 15(2):168-178. doi:10.3176/ tr.2011.2.05.T.

- Talmi D, Frith C: Neurobiology: feeling right about doing right. Nature 2007, 446(7138):865866. doi:10.1038/446865a.

- Tancredi LR: The neuroscience of "free will". Behav Sci Law 2007, 25(2):295-308. doi:10.1002/bsl.749.

- Tankersley D: Psychopathology, neuroscience, and moral theory. Philos Psychiatr Psychol 2011, 18(4):349-357. doi:10.1353/ppp.2011.0044.

- Tankersley D: Neuromorality. Philos Psychiatr Psychol 2011, 18(4):367-369. doi:10.1353/ ppp.2011.0053.

- Tassy S: On the necessity to distinguishing judgment from subjective choice in the cognitive neuroscience of morality]. Med Sci (Paris) 2011, 27(10):889-894. doi:10.1051/medsci/20112710018.

- Tassy S, Le Coz P, Wicker B: Current knowledge in moral cognition can improve medical ethics. $J$ Med Ethics 2008, 34(9):679-682. doi:10.1136/ jme.2006.018812.

- Taylor PL: Responsibility rewarded: ethics, engagement, and scientific autonomy in the labyrinth of the minotaur. Neuron 2011, 70(4):577-581. doi:10.1016/j.neuron.2011.05.009.

- Tersman F: The reliability of moral intuitions: a challenge from neuroscience. Australas $J$ Philos 2008, 86(3):389-405. doi:10.1080/ 00048400802002010.

- Thagard P: The moral psychology of conflicts of interest: insights from affective neuroscience. J Appl Philos 2007, 24(4):367-380. doi:10.1111/ j.1468-5930.2007.00382.x.

- Thomas BC, Croft KE, Tranel D: Harming kin to save strangers: further evidence for abnormally utilitarian moral judgments after ventromedial prefrontal damage. J Cogn Neurosci 2011, 23(9):2186-2196. doi:10.1162/jocn.2010.21591.

- Trémolière B, Neys WD, Bonnefon JF: Mortality salience and morality: thinking about death makes people less utilitarian. Cognition 2012, 124 (3):379-384. doi:10.1016/j.cognition.2012.05.011.

- Tsomo KL: Compassion, ethics and neuroscience: neuroethics through Buddhist eyes. Sci Eng Ethics 2012, 18(3):529-537. doi:10.1007/s11948-0129369-4.
- Tsukiura T, Cabeza R: Shared brain activity for aesthetic and moral judgments: implications for the Beauty-is-Good stereotype. Soc Cogn Affect Neurosci 2011, 6(1):138-148. doi:10.1093/ scan/nsq025.

- Tucker P: Reinventing morality: evolutionary biology and neuroscience are adding to our understanding of a historically unscientific area. Futurist 2009, 43(1):20.

- Van Berkum JJ et al.: Right or wrong? The brain's fast response to morally objectionable statements. Psychol Sci 2009, 20(9):1092-1099. doi:10.1111/j.1467-9280.2009.02411.x.

- Velez Garcia AE, Ostrosky-Solis F: From morality to moral emotions. Int J Psychol 2006, 41(5):348354. doi:10.1080/00207590500345898.

- von Lautz A, Maier S: Autonomy, decisions, and free will. Cogn Process 2011, 12(3):311-313. doi:10.1007/s10339-011-0409-9.

- Wain O, Spinella M: Executive functions in morality, religion, and paranormal beliefs. Int $J$ Neurosci 2007, 117(1):135-146. doi:10.1080/ 00207450500534068.

- Wainryb C: "Is" and "ought": moral judgments about the world as understood. New Dir Child Adolesc Dev 2004, 103:3-18. doi:10.1002/cd.94.

- Waller RR: Beyond button presses: the neuroscience of free and morally appraisable actions. Monist 2012, 95(3):441-462. doi:10.5840/ monist201295323.

- Walter H: Emotional dysfunction, psychopathy, and cognitive neuroscience. What is new and what are the consequences. Nervenarzt 2005, 76(5):557-568.

- Woodward J, Allman J: Moral intuition: its neural substrates and normative significance. J Physiol Paris 2007, 101(4-6):179-202. doi:10.1016/j. jphysparis.2007.12.003.

- Wu Y et al.: Brain activity in fairness consideration during asset distribution: does the initial ownership play a role? PLoS One 2012, 7(6):e39627. doi:10.1371/journal.pone.0039627.

- Xue SW, Wang Y, Tang YY: Personal and impersonal stimuli differentially engage brain networks during moral reasoning. Brain Cogn 2013, 81(1):24-28. doi:10.1016/j.bandc.2012.09.004.

- Young L, Koenigs M: Investigating emotion in moral cognition: a review of evidence from functional neuroimaging and neuropsychology. Br Med Bull 2007, 84:69-79. doi:10.1093/bmb/ ldm031.

- Young L et al.: Disruption of the right temporoparietal junction with transcranial magnetic stimulation reduces the role of beliefs 
in moral judgments. Proc Natl Acad Sci USA 2010, 107(15):6753-6758. doi:10.1073/ pnas.0914826107.

- Young L, Cushman F, Hauser M, Saxe R: The neural basis of the interaction between theory of mind and moral judgment. Proc Natl Acad Sci USA 2007, 104(20):8235-8240. doi:10.1073/ pnas.0701408104.

- Young L, Dungan J: Where in the brain is morality? Everywhere and maybe nowhere. Soc Neurosci 2012, 7(1):1-10. doi:10.1080/ 17470919.2011.569146.

- Young L, Saxe R: An fMRI investigation of spontaneous mental state inference for moral judgment. J Cogn Neurosci 2009, 21(7):1396-1405. doi:10.1162/jocn.2009.21137.

- Young L, Saxe R: It's not just what you do, but what's on your mind: a review of Kwame Anthony Appiah's "Experiments in Ethics". Neuroethics 2010, 3(3): 201-207. doi:10.1007/s12152-010-9066-4.

- Young L, Saxe R: The neural basis of belief encoding and integration in moral judgment. Neuroimage 2008, 40(4):1912-1920. doi:10.1016/j. neuroimage.2008.01.057.

- Youssef FF et al.: Stress alters personal moral decision making. Psychoneuroendocrinology 2012, 37(4):491-498. doi:10.1016/j.psyneuen.2011.07.017.

- Zaidel DW, Nadal M: Brain intersections of aesthetics and morals: perspectives from biology, neuroscience, and evolution. Perspect Bio Med 2011, 54(3):367-380. doi:10.1353/pbm.2011.0032.

- Zak PJ, Kurzban R, Matzner WT: The neurobiology of trust. Ann NY Acad Sci 2004, 1032:224-227. doi:10.1196/annals.1314.025.

- Zak PJ, Kurzban R, Matzner WT: Oxytocin is associated with human trustworthiness. Horm Behav 2005, 48(5):522-527. doi:10.1016/j. yhbeh.2005.07.009.

- Zak PJ, Fakhar A: Neuroactive hormones and interpersonal trust: international evidence. Econ Hum Biol 2006, 4(3):412-429. doi:10.1016/j. ehb.2006.06.004.

- Zak PJ: The neurobiology of trust. Sci Am 2008, 298(6):88-95. doi:10.1038/scientificamerican0608-88.

- Zak PJ, Barraza JA: The neurobiology of collective action. Front Neurosci 2013, 7:211. doi:10.3389/ fnins.2013.00211.

- Zarpentine, C: Neuroethics and the complexity of moral psychology. AJOB Neurosci 2011, 2(2):12-13. doi:10.1080/21507740.2011.559920.

- Zhang L: Moral judgment under perspective of neuroethics. Zi ran bian zheng fa tong xun = Journal of Dialectics of Nature 2008, 3:15.
Books

- Baertschi B: La Neuroéthique: Ce que les Neurosciences font à Nos Conceptions Morales. Paris: Découverte; 2009.

- Baron-Cohen S, Lombardo M, Tager-Flusberg H: (Eds): Understanding Other Minds: Perspectives from Developmental Social Neuroscience. Oxford, U.K.: Oxford University Press; 2013.

- Bickle J: (Ed): The Oxford Handbook of Philosophy of Neuroscience. New York: Oxford University Press; 2009.

- Bickle J: Philosophy and Neuroscience: A Ruthlessly Reductive Account. Amsterdam: Kluwer; 2003.

- Boella L: Neuroetica: La Morale Prima della Morale. Milano: Raffaello Cortina; 2008.

- Brugs R, Issa AM, Postiglione M: Advances in Neuroscience: Social, Moral, Philosophical, Theological Implications: Proceedings of the ITEST Workshop, September, 2002. St. Louis, Mo.: ITEST Faith/Science Press; 2003.

- Burton RA: A Skeptic's Guide to the Mind: What Neuroscience Can and Cannot Tell Us about Ourselves. New York: St. Martin's Press; 2013.

- Cacioppo JT et al.: (Eds): Foundations in Social Neuroscience. Cambridge, Mass.: MIT Press; 2002.

- Callender JS: Free Will and Responsibility: A Guide for Practitioners. Oxford, U.K.: Oxford University Press; 2010.

- Casebeer WD: Natural Ethical Facts: Evolution, Connectionism, and Moral Cognition. Cambridge, Mass.: MIT Press; 2003.

- Changeux JP: (Ed): Neurobiology of Human Values. Berlin: Springer; 2005.

- Churchland PM: Neurophilosophy at Work. Cambridge: Cambridge University Press; 2007.

- Churchland PS: Braintrust: What Neuroscience Tells Us about Morality. Princeton: Princeton University Press; 2011.

- Churchland PS: Brain-Wise: Studies in Neurophilosophy. Cambridge, Mass.: MIT Press; 2002.

- Clausen J, Maier G, Müller O: Die 'Natur des Menschen' in Neurowissenschaft und Neuroethik. Würzburg, Germany: Königshausen \& Neumann; 2007.

- Clayton P, Schloss J: (Eds): Evolution and Ethics: Human Morality in Biological and Religious Perspective. Grand Rapids, Mich.: W. B. Eerdmans Publishing Company; 2004.

- Decety J, Ickes W: (Eds): The Social Neuroscience of Empathy. Cambridge, Mass.: MIT Press; 2009.

- DiSilvestro R: Human Capacities and Moral Status. Dordrecht: Springer; 2010. 
- Ebstein R, Shamay-Tsoory S, Chew SH: (Eds): From DNA to Social Cognition. Hoboken, N.J.: Wiley-Blackwell; 2011.

- Engels EM, Hildt E: Neurowissenschaften und Menschenbild. Paderborn: Mentis; 2005.

- Franks DD: Neurosociology: The Nexus between Neuroscience and Social Psychology. New York: Springer; 2010.

- Gallagher S: How the Body Shapes the Mind. Oxford, U.K.: Clarendon Press; 2005.

- Gazzaniga, MS: The Ethical Brain: The Science of Our Moral Dilemmas. New York: Harper Perennial; 2005.

- Gazzaniga, MS: Wann ist der Mensch ein Mensch? Antworten der Neurowissenschaft auf ethische Fragen. Düsseldorf: Patmos-Verl; 2007.

- Gazzaniga MS: El Cerebro Ético. Barcelona: Paidós; 2006.

- Geyer C: Hirnforschung und Willensfreiheit: zur Deutung der neuesten Experimente. Frankfurt: Suhrkamp; 2004.

- Gillett G: Subjectivity and Being Somebody: Human Identity and Neuroethics. Exeter, UK: Imprint Academic; 2008.

- Giménez Amaya JM, Sánchez-Migallón Granados S. De la Neurociencia a la Neurología: Narrativa Científica y Reflexión Filosófica. Pamplona: Eunsa; 2010.

- Glimcher PW: Decisions, Uncertainty, and the Brain: The Science of Neuroeconomics. Cambridge, Mass.: MIT Press; 2003.

- Gluchman V: (Ed): Morality: Reasoning on Different Approaches. Amsterdam: Rodopi, 2013.

- Greene JD: Moral Tribes: Emotion, Reason, and the Gap Between Us and Them. New York: The Penguin Press; 2013.

- Hagner M: Geniale Gehirne: Zur Geschichte der Elitegehirnforschung. Göttingen: Wallstein Verlag; 2004.

- Harris S: The Moral Landscape: How Science Can Determine Human Values. New York: Free Press; 2010.

- Hauser MD: Moral Minds: How Nature Designed Our Universal Sense of Right and Wrong. New York: Ecco; 2006.

- Heintel P, Broer K: Hirnforschung als dialektische Sozialwissenschaft. Münster: Wien Lit; 2005.

- Jackson F, Pettit P, Smith M: Mind, Morality, and Explanation: Selected Collaborations. Oxford, U.K.: Oxford University Press; 2004.

- Legrenzi P, Umiltà C: Neuromania: On the Limits of Brain Science. Translated by Frances Anderson. Oxford, U.K.: Oxford University Press; 2011.

- Lehrer J: How We Decide. Boston: Houghton Mifflin Harcourt; 2009.
- Metzinger T: The Ego Tunnel: The Science of the Mind and the Myth of the Self. New York: Basic Books; 2009.

- Murphy NC, Ellis GFR, O'Connor T: Downward Causation and the Neurobiology of Free Will. Berlin: Springer Verlag; 2009.

- Noë A: Out of Our Heads: Why You Are Not Your Brain, and Other Lessons from the Biology of Consciousness. New York: Hill and Wang; 2009.

- Pfaff DW: The Neuroscience of Fair Play: Why We (Usually) Follow the Golden Rule. New York: Dana Press; 2007.

- Prinz JJ. The Emotional Construction of Morals. Oxford, U.K.: Oxford University Press; 2007.

- Quartz SR, Sejnowski TJ: Liars, Lovers and Heroes: What the New Brain Science Reveals About How We Become Who We Are. New York: William Morrow; 2002.

- Rees DA, Rose SPR: The New Brain Sciences: Perils and Prospects. New York: Cambridge University Press; 2004.

- Reuter-Lorenz PA, Baynes K, Mangun GR, Phelps EA: (Eds). The Cognitive Neuroscience of Mind: A Tribute to Michael S. Gazzaniga. Cambridge, Mass.: MIT Press, 2010.

- Rolls ET: Memory, Attention, and Decision-Making: A Unifying Computational Neuroscience Approach. Oxford, U.K.: Oxford University Press; 2008.

- Scharifi G: Brauchen Brauchen wir eine neue Ethik?: Herausforderungen der Ethik durch die Neurowissenschaft. Paderborn: Mentis; 2011.

- Schroeder P, Roskies AL, Nichols S: Moral Motivation. Oxford, U.K.: Oxford University Press; 2010.

- Severino SK: Behold Our Moral Body. Psychiatry, Duns Scotus, and Neuroscience. Berlin: De Gruyter; 2013.

- Sinnott-Armstrong W: (Ed): Moral Psychology, Volume 1: The Evolution of Morality-Adaptations and Innateness. Cambridge, Mass.: MIT Press; 2007.

- Sinnott-Armstrong W: (Ed): Moral Psychology, Volume 2: The Cognitive Science of Morality: Intuition and Diversity. Cambridge, Mass.: MIT Press; 2008.

- Sinnott-Armstrong W: (Ed): Moral Psychology, Volume 3: The Neuroscience of Morality: Emotion, Brain Disorders, and Development. Cambridge, Mass.: MIT Press; 2008.

- Smith R: Free Will and the Human Sciences in Britain, 1870-1910. London: Pickering \& Chatto; 2013.

- Sternberg EJ: My Brain Made Me Do It: The Rise of Neuroscience and the Threat to Moral Responsibility. Amherst, N.Y.: Prometheus Books; 2010. 
- Szasz TS: The Meaning of Mind: Language, Morality, and Neuroscience. Syracuse, N.Y.: Syracuse University Press; 2002.

- Tancredi LR: Hardwired Behavior: What Neuroscience Reveals about Morality. Cambridge: Cambridge University Press; 2005.

- Taylor KE: The Brain Supremacy: Notes from the Frontiers of Neuroscience. Oxford, U.K.: Oxford University Press; 2012.

- Thiele LP: The Heart of Judgment: Practical Wisdom, Neuroscience, and Narrative. New York: Cambridge University Press; 2006.

- Thompson E: Mind in Life: Biology, Phenomenology, and the Sciences of Mind. Cambridge, Mass.: Belknap Press; 2007.

- Tracy JL, Robins RW, Tangney JP: (Eds): The SelfConscious Emotions: Theory and Research. New York: Guilford Press; 2007.

- Verplaetse J, De Schrijver J, Vanneste S, Braeckman, J: (Eds): The Moral Brain: Essays on the Evolutionary and Neuroscientific Aspects of Morality. New York: Springer; 2009.

- Verplaetse J: Localizing the Moral Sense: Neuroscience and the Search for the Cerebral Seat of Morality, 1800-1930. Dordrecht: Springer; 2009.

- Verplaetse J: Het Morele Brein: Een Geschiedenis Over de Plaats van de Moraal in Onze Hersenen. Antwerp: Garant; 2006.

- Vilarroya O, i Argimon FF: (Eds): Social Brain Matters: Stances on the Neurobiology of Social Cognition. Amsterdam: Rodopi; 2007.

- Volavka J: Neurobiology of Violence. Washington, DC: American Psychiatric Publishing; 2002.

\section{Book chapters}

- Ackerman S: Neuroscience and morality. In her Hard Science, Hard Choices: Facts, Ethics, and Policies Guiding Brain Science Today. New York: Dana Press; 2006:17-20.

- Ackerman S: Moral decision making in the brain. In her Hard Science, Hard Choices: Facts, Ethics, and Policies Guiding Brain Science Today. New York: Dana Press; 2006:48-51.

- Appiah A: The varieties of moral experience. In his Experiments in Ethics. Boston: Harvard University Press; 2008:121-163.

- Au C: Eine zwei-quellen-theorie der Moral: spekulative Gedanken vor dem hintergrund einer neurologischen Fallstudie. In Zeithorizonte des Ethischen: zur Bedeutung der Temporalität in der Fundamental- und Bioethik. Edited by Georg Pfleiderer; Christoph Rehmann-Sutter (Hrsg.). [... Forschungssymposium "Zeithorizonte des
Ethischen", das wir im Landgut Castelen bei Kaiser august vom 16. bis 18. Oktober 2003 organisiert hatten]. Stuttgart: Kohlhammer; 2006:191-200.

- Blair RJ: Contributions of neuroscience to the understanding of moral reasoning and its development. In Developmental Social Cognitive Neuroscience. Edited by Philip D. Zelazo, Michael Chandler, Eveline Crone. New York: Psychology Press; 2010:269-288.

- Buller S: Brains, lies, and psychological explanations. In Neuroethics: Defining the Issues in Theory, Practice, and Policy. Edited by Judy Illes. Oxford, U.K.: Oxford University Press; 2006:51-60.

- Casebeer WD: Moral cognition and its neural constituents. In Defining Right and Wrong in Brain Science: Essential Readings in Neuroethics. Edited by Walter Glannon. New York: Dana Press; 2007:206-220.

- Churchland PM: Toward a cognitive neurobiology of the moral virtues. In Scientific and Philosophical Perspectives in Neuroethics. Edited by James Giordano, Bert Gordijn. Cambridge: Cambridge University Press; 2010:146-171.

- Churchland PS: Neuroscience: reflections on the neural basis of morality. In Defining Right and Wrong in Brain Science: Essential Readings in Neuroethics. Edited by Walter Glannon. New York: Dana Press; 2007:179-182.

- Churchland PS: Moral decision making and the brain. In Neuroethics: Defining the Issues in Theory, Practice, and Policy. Edited by Judy Illes. Oxford, U. K.: Oxford University Press; 2006:3-16.

- Churchland PS: Inference to the best decision. In The Oxford Handbook of Philosophy and Neuroscience. Edited by John Bickle. Oxford, U.K.: Oxford University Press; 2009:419-430.

- Churchland PS: Human dignity from a neurophilosophical perspective. In Human Dignity and Bioethics: Essays Commissioned by the President's Council on Bioethics. Washington, DC: President's Council on Bioethics; 2008:99-121.

- Damasio A: The neural basis of social behavior: ethical implications. In Defining Right and Wrong in Brain Science: Essential Readings in Neuroethics. Edited by Walter Glannon. New York: Dana Press; 2007:175-178.

- Decety J, Howard LH: A neurodevelopmental perspective on morality. In Handbook of Moral Development. Edited by Melanie Killen, Judith G. Smetana. New York: Psychology Press; 2013:454-474.

- Decety J, Batson CD. Empathy and morality: integrating social and neuroscience approaches. In The Moral Brain: Essays on the Evolutionary and 
Neuroscientific Aspects of Morality. Edited by Jan Verplaetse, Jelle De Schrijver, Sven Vanneste, Johan Braeckman. Netherlands: Springer; 2009:109-127.

- Donald MW: The definition of human nature. In The New Brain Sciences: Perils and Prospects. Edited by Dai Rees, Steven Rose. New York: Cambridge University Press; 2004:34-58.

- Farah MJ, Heberlein AS: Personhood: an illusion rooted in brain function? In Neuroethics: $A n$ Introduction with Readings. Edited by Martha J. Farah. Cambridge, MA: MIT Press; 2010:321-338.

- Gazzaniga MS: The brain produces a poor autobiography. In his The Ethical Brain: The Science of Our Moral Dilemmas. New York: Harper Perennial; 2006:120-144.

- Gazzaniga M: My brain made me do it. In Defining Right and Wrong in Brain Science: Essential Readings in Neuroethics. Edited by Walter Glannon. New York: Dana Press; 2007: 183-194.

- Gillett G: The moral subject. In his Subjectivity and Being Somebody: Human Identity and Neuroethics. Charlottesville: Imprint Academic; 2008:84-106.

- Gillet G: On method in moral science. In his Subjectivity and Being Somebody: Human Identity and Neuroethics. Charlottesville: Imprint Academic; 2008:253-255.

- Glannon W: Brain, body, and self. In his Bioethics and the Brain. New York: Oxford University Press; 2007:13-44.

- Glannon W: Our brains are not us. In his Brain, Body, and Mind: Neuroethics with a Human Face. New York: Oxford University Press; 2011:11-40.

- Glannon W: Neuroscience, free will, and moral responsibility. 41(31); In his Brain, Body, and Mind: Neuroethics with a Human Face. New York: Oxford University Press; 2011:41-71.

- Glannon W: Neuroscience and moral reasoning. In his Brain, Body, and Mind: Neuroethics with a Human Face. New York: Oxford University Press; 2011:93-114.

- Greene J: From neural 'is' to moral 'ought': what are the moral implications of neuroscientific moral psychology? In Defining Right and Wrong in Brain Science: Essential Readings in Neuroethics. Edited by Walter Glannon. New York: Dana Press; 2007:221-236.

- Greene J: Cognitive nuroscience and the structure of the moral mind. In The Innate Mind, Vol. 1. Edited by Peter Carruthers, Stephen Laurence, Stephen Stich. New York: Oxford University Press; 2005:338-352.

- Greene JD: The secret joke of Kant's soul. In Moral Psychology, Vol. 3: The Neuroscience of
Morality: Emotion, Disease, and Development. Edited by W. Sinnott-Armstrong. Cambridge, Mass.: MIT Press; 2007:35-80.

- Greene JD: The cognitive neuroscience of moral judgment. In The Cognitive Neurosciences. Edited by Michael S. Gazzaniga et al. Cambridge, Mass.: MIT Press; 2009:987-1002.

- Haggard P: Neuroethics of free will. In The Oxford Handbook of Neuroethics. Edited by Judy Illes, Barbara J. Sahakian. Oxford, U.K.: Oxford University Press; 2013:219-226.

- Haidt J: The moral emotions. In Handbook of Affective Sciences. Edited by Richard J. Davidson, Klaus R. Scherer, and H. Hill Goldsmith. Oxford, U. K.: Oxford University Press; 2003:852-870.

- Joyce R: What neuroscience can (and cannot) contribute to metaethics. In Moral Psychology, Vol. 3: The Neuroscience of Morality: Emotion, Disease, and Development. Edited by W SinnottArmstrong. Singapore: Wiley-Blackwell; 2007:371394.

- Koenigs M: Emotion and moral cognition. In From DNA to Social Cognition. Hoboken, N.J.: Wiley-Blackwell; 2012:111-122.

- Kollek R: Mind metaphors, neurosciences and ethics. In The New Brain Sciences: Perils and Prospects. Edited by Dai Rees, Steven Rose. New York: Cambridge University Press; 2004:71-87.

- Landreth A: The emerging theory of motivation. In The Oxford Handbook of Philosophy and Neuroscience. Edited by John Bickle. Oxford, U.K.: Oxford University Press; 2009:381-418.

- Levy N: The neuroscience of free will. In his Neuroethics: Challenges for the 21st Century. New York: Cambridge University Press; 2007:222-257.

- Meilaender G: Commentary on Churchland. In Human Dignity and Bioethics: Essays Commissioned by the President's Council on Bioethics. Washington, DC: President's Council on Bioethics; 2008: 122-125.

- Mele A: Free will and neuroscience. In his Free Will and Luck. Oxford, U.K.: Oxford University Press, 2006:30-48.

- Midgley M: Do we ever really act? In The New Brain Sciences: Perils and Prospects. Edited by Dai Rees, Steven Rose. New York: Cambridge University Press; 2004:17-33.

- Moll J, de Oliveira-Souza R, Zahn R: Neuroscience and morality: moral judgments, sentiments, and values. In Personality, Identity, and Character. Edited by Darcia Narvaez, Daniel K. Lapsley. New York: Cambridge University Press; 2009:106-135.

- Nesse RM: How can evolution and neuroscience help us understand moral capacities? In The 
Moral Brain: Essays on the Evolutionary and Neuroscientific Aspects of Morality. Edited by Jan Verplaetse, Jelle De Schrijver, Sven Vanneste, Johan Braeckman. Netherlands: Springer; 2009 New York: Springer; 2009:201-209.

- Rose H: Consciousness and the limits of neurobiology. In The New Brain Sciences: Perils and Prospects. Edited by Dai Rees, Steven Rose. New York: Cambridge University Press; 2004:59-70.

- Rose S: Having a brain, being a mind. In his The Future of the Brain: The Promise and Perils of Tomorrow's Neuroscience. Oxford, U.K.: Oxford University Press; 2006:137-168.

- Roskies A: What's "neu" in neuroethics. In The Oxford Handbook of Philosophy and Neuroscience. Edited by John Bickle. Oxford, U.K.: Oxford University Press; 2009:454-472.

- Roskies A: A case study in neuroethics: the nature of moral judgment. In Neuroethics: Defining the Issues in Theory, Practice, and Policy. Edited by Judy Illes. Oxford, U.K.: Oxford University Press; 2006:17-32.

- Schleim S: Über einen möglichen normativen beitrag der Moralphysiologie. In: Brauchen wir eine neue Moral?: Herausforderungen der Ethik durch die Neurowissenschaft. Edited by Gilbert Scharifi. Paderborn: Mentis; 2011:181-198.

- Suhler C, Churchland PS: The neurobiological basis of morality. In The Oxford Handbook of Neuroethics. Edited by Judy Illes, Barbara J. Sahakian. Oxford, U.K.: Oxford University Press; 2013:33-58.

- Tancredi L: Neuroscience and morality. In his Hardwired Behavior: What Neuroscience Reveals about Morality. New York: Cambridge University Press; 2005:1-11.

- Tancredi L: Morality and the mind. In his Hardwired Behavior: What Neuroscience Reveals about Morality. New York: Cambridge University Press; 2005:12-24.

- Tancredi L: The moral brain. In his Hardwired Behavior: What Neuroscience Reveals about Morality. New York: Cambridge University Press; 2005:34-45.

- Tancredi L: Creating a moral brain. In Hardwired Behavior: What Neuroscience Reveals about Morality. New York: Cambridge University Press; 2005:162-176.

- Tancredi LR: The bad brain: biology of moral thinking. In The Variables of Moral Capacity. Edited by David C. Thomasma and David N. Weisstub. Dordrecht: Kluwer; 2004:235-257.

- Zoloth L: Being in the world: neuroscience and the ethical agent. In Neuroethics: Defining the
Issues in Theory, Practice, and Policy. Edited by Judy Illes. Oxford, U.K.: Oxford University Press; 2006:61-74.

\section{Discussion and conclusions}

Despite our best efforts to amass as complete a bibliography of the past 10 years' neuroethics literature as possible, automated indexing and other technical issues can affect the retrieval of documents. However, this need not constrain the capability of this document to provide a valuable nexus in, and for the discipline. As consistent with Part 1 of this series, we conceive of this bibliography as a participatory endeavor, and request that the readership contribute to this effort by adding any missing citations to the online comments section of this bibliography. Citations also can be emailed directly to the bibliographic manager at: bioethics@georgetown. edu for subsequent inclusion as commentary/addenda to this work.

To be sure, with advances in neuroscientific capabilities and expanding use of neuroscientific techniques and technologies in medicine, arguments are being made to address ethical issues generated by brain research [6], prompting elaboration of neuroethics as the "ethics of neuroscience" [2,7]. Indeed, it is (perhaps most) important to ask if such approaches to studying (moral) cognition and actions are technically apt, valid, and therefore of any real value $[3,8]$. Will necessary review, oversight and guidance be developed to direct and regulate if and how such research should or should not be conducted and translated into clinical treatments? Might studies of the putative neural bases of moral thought and action establish trends to engage these substrates and mechanisms in the clinical practices of neurology and psychiatry, and/or establish a basis for boutique, socially-, legally-, or politically-oriented interventions aimed at altering moral cognition and behaviors? Part 3 of this series will present a current bibliography of these and other neuroethical issues germane to clinical medicine.

In addition to implications for clinical care, neuroscientific studies of cognition, emotion and behavior can be and are increasingly - leveraged in legal and social contexts, which must be considered on an international scale $[9,10]$. How, for example, might neuroscientific insights to the concept of free will incur consequences for questions of legal culpability? Can neuroscience provide metrics for, and standards of psychosocial "normality" and "abnormality" that are valid and viable within and across cultures? How will neuroscience and neurotechnologies be employed upon the twenty first century world stage to affect human health and capability, and evoke economic and political balances of power? Literature addressing these issues and questions will be presented in Part 4 of this bibliographic series. When taken together, we hope 
that this bibliography will elucidate the literature that is representative of the first ten years of this field, provide a historical view of this discipline's growth, and afford insight to its developing canon.

\section{Competing interests}

The authors declare that they have no competing interests.

\section{Authors' contributions}

$M D$ and LB were responsible for data collection; MD and JG were responsible for data interpretation and manuscript preparation, and JG was responsible for study design, and revision and critical review of the manuscript. The authors have approved the final version of the manuscript.

\section{Acknowledgements}

This work was supported in part by funding the Clark Family Foundation, William H. and Ruth Crane Schaefer Endowment, Childrens' Hospital and Clinics Foundation of Minneapolis (JG), and the Neuroethics Studies Program of the Pellegrino Center for Clinical Bioethics of Georgetown University, Washington, DC, USA (JG, LB). The authors thank Sherry Loveless, and Profs. Koji Tachibana and John R. Shook for their assistance in the preparation of this manuscript.

\section{Author details}

'Bioethics Research Library, Kennedy Institute of Ethics, Georgetown University, Washington, DC 20057, USA. ${ }^{2}$ Neuroethics Studies Program, Edmund D. Pellegrino Center for Clinical Bioethics, Georgetown University Medical Center, Washington, DC 20057, USA. ${ }^{3}$ Department of Neurology, Georgetown University Medical Center, Washington, DC 20057, USA. ${ }^{4}$ Human Science Center, Ludwig-Maximilians Universität, München, Germany.

Received: 9 January 2015 Accepted: 14 January 2015

Published online: 15 February 2015

\section{References}

1. Kohls N, Benedikter R. James J. Giordano. In: Giordano JJ, Bert G, editors. Scientific and Philosophical Perspectives in Neuroethics. Cambridge, UK: New York: Cambridge University Press; 2010. p. 37-65.

2. Roskies A. Neuroethics for the new millennium. Neuron. 2002;35(1):21-3. doi:10.1016/50896-6273(02)00763-8.

3. Giordano J. The human prospect(s) of neuroscience and neurotechnology: Domains of influence and the necessity - and questions - of neuroethics. Hum Prospect. 2014;4(1):1-18.

4. Safire W. Our new Promethean gift [conference introduction]. Cerebrum. 2002;4(3):54-5. http://dana.org/Cerebrum/2002/Neuroethics_Mapping_ the_Field http://dana.org/Cerebrum/2002/Neuroethics_Mapping_the_Field.

5. Buniak L, Darragh $M$, Giordano J. A four-part working bibliography of neuroethics: Part 1: overview and reviews_-defining and describing the field and its practices. Philos Ethics Humanit Med. 2014;9:9. doi:10.1186/1747-5341-9-9.

6. Levy N. Neuroethics: Challenges for the 21st Century. Cambridge, New York: Cambridge University Press; 2007.

7. Giordano J. Neuroethics: interacting "traditions" as a viable meta-ethics. AJOB Neurosci. 2011;2(2):17-9. doi:10.1080/21507740.2011.559922.

8. Avram M, Giordano J. Neuroethics: Some things old, some things new, some things borrowed... and to do. AJOB Neurosci. 2014;5(4):1-3.

9. Lanzilao E, Shook J, Benedikter R, Giordano J. Advancing neuroscience on the 21st century world stage: The need for - and proposed structure of - an internationally relevant neuroethics. Ethics Biol Engineer Med. 2013;4(3):211-29.

10. Shook JR, Giordano J. A principled, cosmopolitan neuroethics: Considerations for international relevance. Philos Ethics Humanit Med 2014, 9 (1). http://www.peh-med.com/content/9/1/9.

\section{Submit your next manuscript to BioMed Central and take full advantage of:}

- Convenient online submission

- Thorough peer review

- No space constraints or color figure charges

- Immediate publication on acceptance

- Inclusion in PubMed, CAS, Scopus and Google Scholar

- Research which is freely available for redistribution

Submit your manuscript at www.biomedcentral.com/submit 